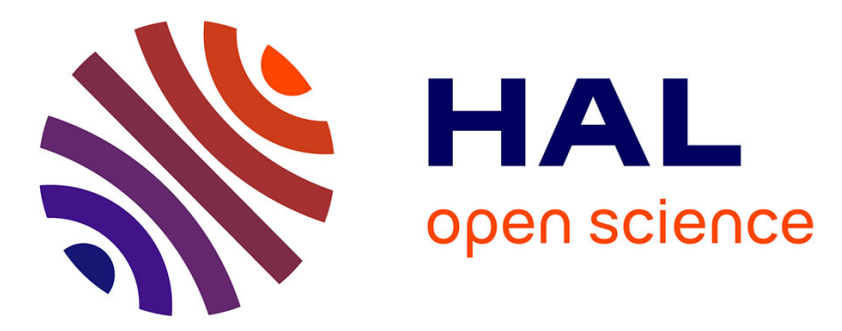

\title{
Trend and variability in a new, reconstructed streamflow dataset for West and Central Africa, and climatic interactions, 1950-2005
}

Moussa Sidibe, Bastien Dieppois, Yu Fisjak, Jean-Emmanuel Paturel, Ernest Amoussou, Babatunde Anifowose, Damian Lawler

\section{To cite this version:}

Moussa Sidibe, Bastien Dieppois, Yu Fisjak, Jean-Emmanuel Paturel, Ernest Amoussou, et al.. Trend and variability in a new, reconstructed streamflow dataset for West and Central Africa, and climatic interactions, 1950-2005. Journal of Hydrology, 2018, 561, pp.478-493. 10.1016/j.jhydrol.2018.04.024 . hal-02106650

\section{HAL Id: hal-02106650 \\ https://hal.umontpellier.fr/hal-02106650}

Submitted on 23 Apr 2019

HAL is a multi-disciplinary open access archive for the deposit and dissemination of scientific research documents, whether they are published or not. The documents may come from teaching and research institutions in France or abroad, or from public or private research centers.
L'archive ouverte pluridisciplinaire HAL, est destinée au dépôt et à la diffusion de documents scientifiques de niveau recherche, publiés ou non, émanant des établissements d'enseignement et de recherche français ou étrangers, des laboratoires publics ou privés.

\section{(1) (1) $\$$}

Distributed under a Creative Commons Attribution - NonCommercial - NoDerivatives| 4.0 


\section{Trend and variability in a new, reconstructed streamflow dataset for West and Central Africa, and climatic interactions, $1950-2005$}

Sidibe, M, Dieppois, B, Mahé, G, Paturel, J-E, Amoussou, E, Anifowose, B \& Lawler, D

Author post-print (accepted) deposited by Coventry University's Repository

Original citation \& hyperlink:

Sidibe, M, Dieppois, B, Mahé, G, Paturel, J-E, Amoussou, E, Anifowose, B \& Lawler, D 2018, 'Trend and variability in a new, reconstructed streamflow dataset for West and Central Africa, and climatic interactions, 1950-2005', Journal of Hydrology, vol. 561, pp. 478-493.

https://dx.doi.org/10.1016/j.jhydrol.2018.04.024

$\begin{array}{ll}\text { DOI } & 10.1016 / j . j h y d r o l .2018 .04 .024 \\ \text { ISSN } & 0022-1694 \\ \text { ESSN } & 1879-2707\end{array}$

Publisher: Elsevier

NOTICE: this is the author's version of a work that was accepted for publication in Journal of Hydrology. Changes resulting from the publishing process, such as peer review, editing, corrections, structural formatting, and other quality control mechanisms may not be reflected in this document. Changes may have been made to this work since it was submitted for publication. A definitive version was subsequently published in Journal of Hydrology, (561), (2018) DOI:

10.1016/j.jhydrol.2018.04.024

(C) 2018, Elsevier. Licensed under the Creative Commons AttributionNonCommercial-NoDerivatives 4.0 International http://creativecommons.org/licenses/by-nc-nd/4.0/

Copyright $\odot$ and Moral Rights are retained by the author(s) and/ or other copyright owners. A copy can be downloaded for personal non-commercial research or study, without prior permission or charge. This item cannot be reproduced or quoted extensively from without first obtaining permission in writing from the copyright holder(s). The content must not be changed in any way or sold commercially in any format or medium without the formal permission of the copyright holders.

This document is the author's post-print version, incorporating any revisions agreed during the peer-review process. Some differences between the published version and this version 
may remain and you are advised to consult the published version if you wish to cite from it. 


\section{Accepted Manuscript}

Research papers

Trend and variability in a new, reconstructed streamflow dataset for West and

Central Africa, and climatic interactions, 1950 - 2005

Moussa Sidibe, Bastien Dieppois, Gil Mahé, Jean-Emmanuel Paturel, Ernest

Amoussou, Babatunde Anifowose, Damian Lawler

PII:

S0022-1694(18)30277-4

DOI:

https://doi.org/10.1016/j.jhydrol.2018.04.024

Reference:

HYDROL 22727

To appear in:

Journal of Hydrology

Received Date: 26 October 2017

Revised Date: $\quad 30$ March 2018

Accepted Date: $\quad 7$ April 2018

Please cite this article as: Sidibe, M., Dieppois, B., Mahé, G., Paturel, J-E., Amoussou, E., Anifowose, B., Lawler, D., Trend and variability in a new, reconstructed streamflow dataset for West and Central Africa, and climatic interactions, 1950 - 2005, Journal of Hydrology (2018), doi: https://doi.org/10.1016/j.jhydrol.2018.04.024

This is a PDF file of an unedited manuscript that has been accepted for publication. As a service to our customers we are providing this early version of the manuscript. The manuscript will undergo copyediting, typesetting, and review of the resulting proof before it is published in its final form. Please note that during the production process errors may be discovered which could affect the content, and all legal disclaimers that apply to the journal pertain. 


\section{Trend and variability in a new, reconstructed streamflow dataset for West and Central Africa, and climatic interactions, 1950 - 2005}

Moussa Sidibe ${ }^{1}$, Bastien Dieppois ${ }^{1,2,3}$, Gil Mahé ${ }^{4}$, Jean-Emmanuel Paturel ${ }^{4}$, Ernest Amoussou ${ }^{5}$, Babatunde Anifowose ${ }^{6}$, Damian Lawler ${ }^{1}$

${ }^{1}$ Centre for Agroecology, Water and Resilience (CAWR), Coventry University, Coventry, UK

${ }^{2}$ Department of Oceanography, University of Cape Town, Cape Town, RSA

${ }^{3}$ School of Geography, Earth and Environmental Sciences, University of Birmingham, Birmingham, UK

${ }^{4}$ HydroSciences (HSM), IRD, Montpellier, France

${ }^{5}$ Département de Géographie et Aménagement du Territoire (DGAT), Université de Parakou, Parakou, Benin

${ }^{6}$ School of Energy, Construction \& Environment, Coventry University, UK

\section{Abstract}

Over recent decades, regions of West and Central Africa have experienced different and significant changes in climatic patterns, which have significantly impacted hydrological regimes. Such impacts, however, are not fully understood at the regional scale, largely because of scarce hydroclimatic data. Therefore, the aim of this study is to (a) assemble a new, robust, reconstructed streamflow dataset of 152 gauging stations; (b) quantify changes in streamflow over 1950 - 2005 period, using these newly reconstructed datasets; (c) significantly reveal trends and variability in streamflow over West and Central Africa based on new reconstructions; and (d) assess the robustness of this dataset by comparing the results with those identified in key climatic drivers (e.g. precipitation and temperature) over the region. Gap filling methods applied to monthly time series (1950-2005) yielded robust results (median Kling-Gupta Efficiency >0.75). The study underlines a good agreement between precipitation and streamflow trends and reveals contrasts between western Africa (negative trends) and Central Africa (positive trends) in the 1950s and 1960s. Homogenous dry conditions of the 1970s and 1980s, characterized by reduced significant negative trends resulting from quasi-decadal modulations of the trend, are replaced by wetter conditions in the recent period (1993-2005). The effect of this rainfall recovery (which extends to West and Central Africa) on increased river flows are further amplified by land use change in some Sahelian basins. This is partially offset, however, by higher potential evapotranspiration rates over parts of Niger and Nigeria. Crucially, the new reconstructed 
streamflow datasets presented here will be available for both the scientific community and water resource managers.

Keywords: West and Central Africa, streamflow trend and variability, hydroclimate variability, multitemporal trend identification, gap filling methods.

\section{INTRODUCTION}

Rainfall in Africa during the $20^{\text {th }}$ century was characterized by decreasing annual trends over the continent except regions in Cameroon, Sierra Leone and southern equatorial Africa (Hulme et al., 2001). Since 1950, most of the extreme climatic conditions occurred in the Sahel region, which has experienced several drought events from the end of the 1960s to the 1990s (Dai et al., 2004; Lebel, 2003; Nicholson, 2013). For the 1968-1997 period, rainfall in August in the West African Sahel showed a decrease of up to 37\% compared to the 1931-1960 period (Nicholson et al., 2000). Rainfall patterns in the post-1990 period are, however, less well documented, given data scarcity: this has led to controversial findings regarding the end of Sahel drought. For example, Ozer et al. (2003) claimed that the Sahel drought ended in the 1990s, whereas L'Hôte et al. (2002) suggested that the drought continued beyond the 1990s. These contradictions partly reflect the significant changes in the spatial distribution of precipitation, which make findings highly dependent on the specific region, and the years and even months considered. This underlines the need for studies covering larger spatial scales. However, there is agreement on an increase in annual rainfall over the West African Sahel since the 1990s (e.g. Ali and Lebel, 2009; Jury, 2013; Lebel and Ali, 2009; Mahé and Paturel, 2009). See also Maidment et al. (2015), who described rainfall trends over Africa during the period 1983-2010, using different observational datasets and simulations from the current state-of-the-art global climate models.

Interestingly, while rainfall variability has been investigated at the continental scale in Africa, its effects on runoff regimes have mostly been investigated at catchment scales, using different statistical approaches and hydrological models (e.g. Ibrahim et al., 2015). This is mainly due to restricted data, and several factors 
(e.g. Gyau-Boakye and Schultz, 1994) resulted in missing values in streamflow records. Such data restrictions have limited attempts to systematically assess streamflow trend, variability and changes at the regional scales. Descroix et al. (2009) reported a negative trend (more than $15 \%$ decrease) in streamflow for the 1960-2010 period in Sudanian regions (receiving approximately 700 - $1300 \mathrm{~mm}$ yr-1 annual rainfall) as a response to changes in rainfall regimes. Also, Mahé et al. (2013) found that a decrease in annual rainfall of around $20 \%$ since 1970 has resulted in a streamflow decrease of up to $60 \%$ for some rivers in West Africa (e.g. Niger and Senegal rivers). Amogu et al. (2010), in their attempt to regionalize runoff evolution over western Africa (1950-2010), found a clear difference between the Sahelian zone (where, curiously, runoff increases despite reduction in rainfall) and Sudanian and Guinean areas (where runoff decreases logically with rainfall). While major rivers of West Africa show a distinct runoff decrease since 1970, river flows in Central Africa do not show any long-term trend (Mahé et al., 2013). However, these results are restricted to a few long and gap-free time series, making it difficult to describe regional streamflow variability.

Changes in the observational networks (e.g. station locations, gauge maintenance and data collection methods) have limited attempts to study streamflow trends and variability at regional scales. Different gap filling methods have been used (e.g. regression analysis, time series analysis, artificial neural network and interpolation). Multiple imputations approaches, such as proposed by Rubin (1987), were recently implemented to construct a complete rainfall-runoff database in Iran (Kalteh and Hjorth, 2009). More complex methods such as artificial neural networks (Kim and Pachepsky, 2010) and random forest-based approaches (Stekhoven and Bühlmann, 2012) have also been implemented for gap filling problems with satisfactory results. Despite many hydrological data gap filling studies, few African examples exist. Most African studies focus on gap-free stations (e.g. Nka et al.,2015) or reconstructions using linear interpolation techniques. A decision support system based on length of data-gaps, seasons, climatic zones, model performances and data availability has been provided by Gyau-Boakye and Schultz (1994), but such a system would be difficult to implement at the regional scale due to substantial input data requirement and it 
may result in: i) spatially non-homogenous reconstructions, and ii) non-statistically independent reconstructions from climate variables. The development of regional climate models (RCM) also open new prospects for hydrological data reconstruction. For instance, Moalafhi et al. (2017), testing such approaches over the Limpopo basin, in southern Africa, found that dynamical downscaling of reanalysis products can be very useful for semi-arid, data-scarce environments. However, important biases in RCM physics combined with uncertainties in hydrological modeling could substantially impact the quality of streamflow estimates. The present study aims at (1) providing a new, robust reconstructed streamflow dataset, using only streamflow records as predictands, over West and Central Africa, and (2) using the new dataset, together with gridded climatic data, to examine and assess flow changes and variability over the region between 1950 and 2005. This paper is organized as follows. After introducing the study area and the different datasets in section 2, we present the methods in section 3. In section 4.1, two gap filling methods are used to generate a robust and complete streamflow dataset for West and Central Africa. Then, we examine changes (abrupt and gradual) and variability in streamflow, and we compare these results to those observed in climatic variables from section 4.2 to section 4.4. Results are interpreted, and their wider implications discussed in Section 5.

\section{STUDY AREA AND DATASETS}

\subsection{Research Area}

The study area covers West and Central Africa, from $-10^{\circ} \mathrm{N}$ to $25^{\circ} \mathrm{N}$ and $-20^{\circ} \mathrm{E}$ to $30^{\circ} \mathrm{E}$. The selection of the research area was motivated by the key importance of climate change and variability in this region, which also has a dense streamflow gauging network (Figure 1). Some records were short or incomplete, mainly due to equipment failure, instrumentation maintenance issues and sometimes political instability. Most hydrological studies in the region primarily refer to four eco-climatic zones, which are based on both annual rainfall amounts and agricultural properties (FAO, 2004; Roudier et al., 2014): (a) the Sahelian zone (mean annual precipitation ranges between 250 and $500 \mathrm{~mm}$ yr-1), (b) the Sudano-sahelian zone (mean 
102

103

104

105

106

107

108

109

110

111

112

113

114

115

116

117

118

119

120

121

122

123

124

125

126

annual precipitation ranges between 500 to $900 \mathrm{~mm}$ yr-1), (c) the Sudanian zone (mean annual precipitation ranges from 900 to $1100 \mathrm{~mm} \mathrm{yr}-1$ ) and (d) the Guinean zone (mean annual precipitation exceeds $1100 \mathrm{~mm}$ yr-1). However, more complex classifications based on seasonal to interannual variability of rainfall can be found (Badr et al., 2016; Hermann and Mohr, 2011; Janicot, 1992; L’Hôte et al., 1996; Mahé et al., 2001).

West African rainfall is primarily related to the displacement of the Intertropical Convergence Zone (ITCZ), which results in two major seasonal cycles. Regions with less than $\sim 1100 \mathrm{~mm}$ yr-1 annual rainfall are characterized by a single rainy season with a maximum in August, while, further south, the rainfall seasonal cycle is characterized by two rainy seasons (September-November and March-July) (e.g. L’Hôte et al., 1996; Roudier et al., 2014). The boundary between these two zones is however not very clear, with areas experiencing both cycles from year to year because of high rainfall variability (e.g. Le Barbé et al., 2002).

These different rainfall patterns result in different streamflow regimes. If the characteristics of the flow hydrographs coincide with the rainfall seasonal cycle, aspects such as the timing of the peak and the shape of hydrographs are mainly related to the size and physical properties of drainage basins (Roudier et al., 2014). For example, headwater catchments in the Niger river basin (e.g. Mopti, Koulikoro), are characterized by hydrographs with shorter lag times compared to their downstream counterparts (e.g. Niamey, Malanville).

Figure 1: Study area with locations of the main catchments (grey shaded), the river network (blue) and streamflow gauges collected from the SIEREM database (light blue dots).

Furthermore, water related issues have led to the construction of several hydraulic structures, which can have significant impacts on hydrological regimes in some basins. According to the Global Reservoir and Dam database (GRanD; Lehner et al.,2011), large dams (capacity $>10^{6} . \mathrm{m}^{3}$ ), as defined by the International Commission on Large Dams (ICOLD; http://www.icold-cigb.net/GB/Dictionary/dictionary.asp), are primarily located in the Volta basin (53.5\%) and in the Niger River basin (35.2\%; Figure 2). The other large dams are distributed within the Lake Chad basin (9.4\%), the Senegal River basin (1.2\%) and the 
127 Congo basin (<1\%; Figure 2). This corroborates the study by Adeaga et al. (2012) who found that the Volta 128 River and the lower Niger River are the most impacted rivers in western Africa. A summary of the key 129 characteristics of the existing major water resource schemes (hydropower, irrigation) in the Volta basin is 130 provided by McCartney et al. (2012).

131 Figure 2: Large dams (Capacity $>10^{6} . \mathrm{m}^{3}$ ) in the study area and their start of operation (purple: 1920-1950; blue: 1950132 1970; green:1970-1990; red: 1990-2006). Data source: Global Reservoir and Dam database (GRanD; Lehner et al., 2011).

Mean daily streamflow data were collected from the SIEREM ("Système d'Informations

136 Environnementales sur les Ressources en Eaux et leur Modélisation”) database, which initially consisted of 137 data collected by the "Institut de Recherche pour le Dévelopement" (IRD). Further developments include 138 data quality assessment and a coupling to gridded environmental data over West and Central Africa (Boyer 139 et al., 2006). Station metadata and GIS format files (basin contours, hydrological network, soil water 140 holding capacity, vegetation, and geology) can freely be retrieved from 141 http://www.hydrosciences.org/sierem. Additional streamflow data for the Niger River (Idah, Lokoja, 142 Makurdi and Onitsha) were collected from the National Inland Waterways Authority of Nigeria.

143 Over the study area, 863 daily streamflow datasets were collected, and monthly time series were generated 144 but only for the complete months. The percentage of missing data was then calculated for the entire region 145 (Figure 3A), and only stations with less than 50\% missing records were selected for analysis. This approach covered most of the study area, and rigorously minimized reconstruction errors. (see Appendix A for the

147 list of reconstructed stations). Figure 3B shows that most gaps are in the 1950s and 2000s for the 152 148 selected stations. This is due, in some countries, to the absence of gauging stations (e.g. Burkina Faso) and 149 lack of updated records for the recent period (e.g. Central African Republic).

150 Figure 3: A) River network (blue lines) and spatial distribution of stream gauges over the study area, and with their 151 percentage of missing data (purple $=\mathbf{0 - 2 5 \%}$, blue $=\mathbf{2 5 - 5 0 \%}$, green=50-75\% and red $=>\mathbf{7 5 \%}$. Major catchments are 
152

displayed in grey shaded. B) Time-evolution of missing values for the 152 selected stream gauges. Missing values are in red, while observations are in grey. Stations are ordered by country (BF: Burkina Faso, BJ: Benin, CF: Central African Republic, CG: Democratic Republic of Congo, CI: Cote d'Ivoire, CM: Cameroon, GA: Gabon, GH: Ghana, GN: Guinea Conakry, ML: Mali, NG: Nigeria, SN: Senegal, TD: Chad, TO: Togo). The black line represents the number of records per month over the study area for the 1950-2005 period.

\subsubsection{Gridded climate data}

To investigate climate variability and its impact on streamflow regimes over West and Central Africa, gridded monthly climatic datasets (P, T, PET) from the Climatic Research Unit (Mitchel and Jones, 2005) were used. The dataset consists of monthly climatic data for the entire world (generated with more than 4000 weather stations at the global scale) at half a degree resolution. The development of this database required seven data sources, the most important being: the Global Historical Climatology Network (GHCN; Peterson and Vose, 1997), Jones Surface Temperature Anomaly dataset (Jones, 1994; Jones and Moberg, 2003) and Hulme Historical Monthly Precipitation (Hulme et al., 1998). The latest release (CRU TS v.4.00) was preferred as it was built using a new gridding technique (Angular Distance Weighting), which provides more robust results due to a better selection of observation stations for gridding (Harris and Jones, 2017). Unlike precipitation and temperature, which are observed variables, potential evapotranspiration was derived based on a variant of the Penman-Monteith formula, i.e. the FAO (Food and Agricultural Organization) grass reference evapotranspiration equation (Ekström et al.,2007), which assumes a homogenous grass surface ( $0.12 \mathrm{~m}$ height) with no moisture stress, surface albedo of 0.23 and bulk surface resistance of $0.70 \mathrm{~s} / \mathrm{m}$. All climate variables are measured at 2m AGL (Above Ground Level), except for wind speed (commonly recorded at 10m AGL) which has been reduced to $2 \mathrm{~m}$ AGL using a conversion coefficient. Absolute values of the different variables were computed using the baseline values (i.e. 19611990 long-term average) (see Harris et al., 2014; Appendix 1).

Even though the high spatial resolution of the dataset makes it very convenient for investigating local processes, limited number of operational stations over West and Central Africa before 1940 could have resulted in inconsistencies in the CRU dataset (Mitchell and Jones, 2005). Therefore, analyses in this study 
178

179

180

181

182

183

184

185

186

187

188

189

190

191

192

193

194

195

196

197

198

199

200

201

will be performed from 1950 to 2005. In addition, Harris et al. (2014) compared the CRU dataset to datasets developed by the University of Delaware (UDEL) and the Global Precipitation Climatology Centre (GPCC), which both used different observation datasets, interpolation and quality control techniques than the CRU dataset and found good agreement. For instance, for the period considered in this study, mean annual precipitation values from the CRU dataset and the GPCC dataset have a correlation coefficient of 0.9885 significant at $p \leq 0.1$.

\section{METHODOLOGY}

Methods have been implemented using $\mathrm{R}$, a free software environment for statistical computing and graphics (https://www.R-project.org/).

\subsection{Gap filling Methods}

Although parametric gap-filling methods are more commonly used (e.g. Gyau-Boakye and Schultz, 1994; Kalteh and Hjorth, 2009), non-parametric tests are more suitable for hydroclimate variables, as there is no assumption regarding the distribution of the data. Both parametric and non-parametric gap filling methods are therefore tested in this study to generate robust streamflow reconstructions.

\subsubsection{Multiple Imputation by Chained Equations (MICE)}

Based on a set of imputation models defined for individual variables with missing values, Multiple Imputation by Chained Equations (MICE; Van Buuren and Oudshoorn, 1999) is a practical approach for handling missing data. The method has been successfully tested for both continuous and categorical variables in hydrology (e.g. Kalteh and Hjorth, 2009).

In this study, for each incomplete streamflow record, the first step consists of imputing missing values by randomly sampling with replacement from the distribution of observed values. The observed values of each streamflow station are then regressed to other streamflow stations, and missing values are completed by simulated draws from the corresponding posterior predictive distribution of the considered variable (e.g. observed values of $x_{1}$ are regressed on all other variables $x_{2} \ldots x k$, and the missing values of $x_{1}$ are sampled 
202 from its posterior predictive distribution). Several simulations are required to generate a stable single 203 reconstructed streamflow dataset, and the process is repeated several times to generate multiple complete 204 streamflow datasets. In most applications, linear regression models are used for imputing normally 205 distributed continuous variables. The different steps are summarized below:

206 Considering an incomplete variable $\mathrm{z}$ (with $n_{\text {obs }}$ observed values) to be reconstructed using other complete 207 variables $X=\left(x_{1} \ldots x_{2}\right)$ the following linear model is used:

$$
\mathrm{z} \mid \mathrm{x} ; \beta \sim \mathrm{N}\left(\beta \mathrm{x}, \sigma^{2}\right)
$$

Let $\hat{\beta}$ be a row vector of length $k$, a realization of the estimated parameters from fitting the model with the 210 observed $z \cdot V$ represents the covariance matrix of $\widehat{\beta}$, and $\hat{\sigma}$ the estimated root mean-squared error. 211 Imputation parameters $\sigma^{*}$ and $\beta^{*}$ are drawn from the exact joint distribution of $\sigma, \beta$ such that:

$$
\sigma *=\hat{\sigma} \sqrt{(\text { nobs }-k) / g}
$$

$$
\beta * \hat{\beta}+\frac{\sigma *}{\hat{\sigma}} u_{1} V^{1 / 2}
$$

with $g$, a random draw from a $\chi^{2}$ distribution on $n_{o b s}-k$ degrees of freedom, $u_{1}$ a row vector of $k$ independent random draws from a standard Normal distribution and $V^{1 / 2}$ the Cholesky decomposition of $V$.

216 For each missing observation $z_{i}$ estimates are calculated:

$$
z_{i}^{*}=\beta^{*} x_{i}+u_{2 i} \sigma^{*}
$$

where $u_{2 i}$ is a random draw from a standard normal distribution.

As the normal assumption is not often valid for streamflow data (e.g. Kundzewicz and Radziejewski, 2006), missing values were estimated using the Predictive Mean Matching (PMM) approach, which eq. 4, PMM identifies $\alpha$ elements with the smallest error $\left|\hat{\beta} x_{h}-\beta^{*} x_{i}\right|(h=1, \ldots$, nobs). One of these elements is randomly selected and the imputed value of $z_{i}$ is $z_{i}$. The method was implemented using 50 iterations and 100 multiple imputations, which produce a standard deviation only $0.25 \%$ wider than a case 
of infinite multiple imputations according to Rubin (1987). The median was taken as the better estimate to combine the multiple reconstructed datasets.

\subsubsection{Random forest-based reconstruction}

The method is based on the random forest (RF) technique (Breiman, 2001), and involves iteratively training a RF on observed values for predicting the missing values. This method was chosen for its ability to perform under high dimensions, complex interactions and non-linearity (Stekhoven and Bühlmann, 2012). Furthermore, compared to other gap filling methods (e.g. KNNimpute: Troyanskaya et al., 2001; MICE: Van Buuren and Oudshoorn, 1999), it does not require tuning parameters and prior knowledge of the data, making it computationally attractive. The main limitation, however, is the lack of understanding around the construction of the different trees. The different steps are presented below:

Assuming $X=\left(X_{1}, X_{2}, \ldots \ldots \ldots . X_{p}\right)$ a $n^{*} p$-dimensional dataset (in our case $n$ observations and $p$ streamflow gauges), the missing values are estimated based on a RF trained on the observed parts of the dataset. For a given gauging station $X_{s}$ with missing values at the indices $i_{m i s}{ }^{(s)}$, the dataset is separated in four parts:

- The observed streamflow values at the station $X_{s}$, denoted by $Y^{(s)}{ }_{o b s}$;

- The missing values at the station $X_{s}$, denoted by $Y^{(s)}{ }_{m i s}$;

- The other gauging stations with streamflow records at the indices $i^{(s)}{ }_{o b s}=\{1, \ldots n\} \backslash i^{(s)}{ }_{m i s} \operatorname{denoted} X^{(s)}{ }_{o b s}$

- The other gauging stations with streamflow records at $i^{(s)}{ }_{m i s}$ denoted by $X^{(s)}{ }_{m i s}$.

The initial step consists of an initial guess of missing values using mean values. The data frame is then sorted and gauging stations are placed in increasing order, based on the proportion of missing data. For each gauging station $X_{s}$, the missing data is imputed by first fitting a RF taking $Y^{(s)}{ }_{o b s}$ as response variable and $X^{(s)}{ }_{o b s}$ as predictors; then estimating missing values $Y^{(s)}{ }_{m i s s}$ by applying the trained RF to $X^{(s)}{ }_{m i s}$. The procedure is repeated until the difference between the newly filled data matrix and the previous one increases for the first time. The stopping criteria is defined as follows:

$$
\Delta=\frac{\sum_{j \in N}\left(X_{\text {new }}^{i m p}-X_{\text {old }}^{i m p}\right)^{2}}{\sum_{j \in N}\left(X_{\text {new }}^{\text {imp }}\right)^{2}}
$$


The simulations were performed using 1000 trees with the maximum number of iterations set to 100 .

\subsubsection{Validation of gap filling methods}

The validation method used to assess the performance of the implemented reconstruction techniques involves generating artificial gaps in the time series, performing the reconstructions on the new dataset and estimating agreements between predictions and observations. Over the study area, the assumption of data missing completely at random was considered. First, observed values (12, 24, 36, 48, 60 and 120 months) over the entire period, 1950-2005, were randomly removed in each of the stations and later compared to the predictions. Secondly, we randomly removed entire segments of observed data to assess the ability of the gap filling methods to reconstruct contiguous missing data. The modified Kling-Gupta Efficiency (KGE) was used as an indicator of agreement between observations and predictions. This efficiency criterion ensures that the temporal dynamics (measured by the correlation coefficient) as well as the distribution of flows (measured by both the bias and variability ratio) are well represented (Kling et al., 2012).

\subsection{Step change detection and trend analysis}

Changes (natural or artificial) in hydro-climatic time series can occur abruptly (step change) or gradually (trend) or in more complex forms (Machiwal and Jha, 2006). Step-like changes, induced by reservoir construction and changes of gauging structures, for example, might also result from gradual changes since nonlinear system dynamics may show cumulative effects and thresholds (Kundzewicz and Radziejewski, 2006). In this study, step-like changes in the mean are investigated in reconstructed mean annual streamflow time series using a multiple change-points detection analysis (Killick and Eckley, 2014). This technique, which is similar to the method proposed by Hubert et al. (1989), is based on the segment neighborhood algorithm (Auger and Lawrence, 1989). The non-parametric cumulative sum test statistic (Page, 1954) is used to assess the optimal position of change-points.

Linear trends are then investigated for periods defined based on the results of the multiple change-points analysis at the regional scale. The significance of the Mann-Kendall (MK) test (Kendall, 1975; Mann, 
274

1945) is highly sensitive to positive serial correlation (Von Storch, 1995), so its variant (Yue et al., 2002) was preferred for linear trend detection here. The Yue et al. (2002) method assumes trends are linear; datasets are first detrended before extracting the lag-1 serial correlation from the detrended series (i.e. a trend-free pre-whitening procedure (TFPW) which should generate independent residuals series). The detected trend and the residuals are combined, before the MK test for significance is applied. The Theil Sen Approach (TSA) is used to estimate the slope of the trend in a dataset. This approach is less sensitive to outliers and therefore provides a better estimate of slope for skewed data, compared to regression methods.

In addition, as trend values are highly dependent on start and end dates, a multitemporal trend analysis approach has been implemented here (Liebmann et al., 2010; McCabe and Wolock, 2002). Trends here are calculated for all possible segments (minimal length of 5 years) from 1950 to 2005 to explore and define the time series internal variability. For each time series, the multitemporal trend analysis generates a diagram in which each possible pair of start and end dates is associated with a trend value. To investigate the spatial extent and zonal coherence of the different variability patterns in precipitation and streamflow, the multi-temporal trend analysis results were grouped using hierarchical clustering, using the Euclidean distance as the metric of dissimilarity. Different approaches exist to determine the optimal number of clusters (Charrad et al., 2014), but we used the multiscale bootstrapping approach of Suzuki and Shimodaira (2006), which allows uncertainty estimation for each cluster. This is achieved through thousands of bootstraps resampling and used to estimate the probability that a cluster appears in the replicates.

\section{RESULTS AND DISCUSSIONS}

\subsection{Reconstruction outputs}

Two reconstruction methods were applied to the subset of streamflow stations with less than $50 \%$ missing data (i.e. 152 streamflow gauges here). All 152 stations were reconstructed with satisfactory results as illustrated in Figures 4 and 5. 
The validation shows that gap filling methods perform well for both cases of randomly removed observations and contiguous missing segments. Figure 4 shows that the median of the KGE is always greater than 0.75 , which indicates that for half of the stations, the worst component (e.g. correlation, bias ratio or variability ratio) is higher or equal to 0.75 : this suggests good reconstruction performance. Very similar results were achieved using the Nash-Sutcliffe Efficiency and the normalized Root Mean Squared Error (not shown). Also, both methods are reasonably stable when artificially increasing the number of missing observations and when artificially increasing the length of missing segments, despite an artefact suggesting better performances with increasing missing data, which is in fact caused by the sensitivity of efficiency criteria to sample size (e.g. Schönbrodt and Perugini, 2013). However, MICE seem to perform better than RF when increasing the number and the length of missing data (Figure 4).

Figure 4: Validation of gap filling methods: boxplot of validation efficiencies for all the reconstructed stations; upper panels for randomly removed values and lower ones for cases of randomly missing data segments. A red line is drawn at KGE $=0.75$. Outliers are represented in blue dots.

To compare both gap filling methods, results from five stations from different climatic zones and hydrological regimes are presented in Figure 5. While both methods show similar results overall, significant dissimilarity appears in some cases, such as in the Niger River at Niamey, where MICE show an abrupt increase in minimum flow, and decrease in peak flow from 1999 (Figure 5). This pattern, which is similar to those induced by large dams (higher low flows and lower peak flows in downstream reaches), is not consistent with recent studies in the region (e.g. Amogu et al., 2010; Mahé et al., 2013), highlighting increased runoff coefficients at Niamey from the 1990s. MICE generate estimates of missing values by sampling from the observed values and might therefore fail at reconstructing flows beyond observed ranges. Thus, even though MICE often seem to provide better estimates than the RF based method, the latter appears to be more appropriate in the context of changing hydrological regimes, because of its ability to capture complex nonlinear relations between predictors and predictands. 
Figure 5: Reconstructed time series for five streamflow stations representative of different climatic conditions: Wayen (Sahelian), Bonou (Tropical humid), Mbasso (Tropical humid), Niamey (Tropical humid, Sudanian and Sahelian), Bangui (Tropical humid). Blue lines represent observations; black dotted lines represent MICE estimates and Red dotted lines represent Random Forest estimates. Red Boxes highlight time windows of interest.

\subsection{Streamflow changes between 1950 and 2005}

With the assumption that two major break points occurred in the streamflow time series, the step change analysis detected changes in 147 stations over the study area. Both reconstruction methods presented similar results and only those of random-forest based reconstructions are presented. At the regional scale, the first discontinuity in mean annual streamflow occurred in 1970 (Figure 6), with a marked negative shift in the mean (up to $-60 \%$ ). Similar results were found by Hubert et al. (1989), for the Niger and Senegal rivers. The second discontinuity at the regional scale occurred around 1993 and is characterized by a positive shift for more than $70 \%$ of the stations (with an average increase of about $+23 \%$, Figure 6). Despite this positive shift in mean streamflow, recent conditions are still below the 1950s and 1960s wet periods.

Some sub-regional differences, however, emerge along the Gulf of Guinea and regions in Central Africa, where a discontinuity in the mean annual streamflow occurred in the 1950s and early 1960s, with an average positive shift of around 18\% (Figure 6). These results are consistent with the findings of Mahé et al. (2001), underlining differences in rainfall variability between West and Central Africa from 1951 to 1989. Also, some discontinuities are revealed before the 1990s in some stations (Figure 6), probably induced by the wet episodes observed at the end of the 1980s. Based on the data collected from the Global Reservoir and Dam database (GRanD; Lehner et al.,2011), presented in Figure 2, regional scale discontinuities in streamflow were more likely induced by climate variability and land use change rather than reservoirs as only 4\% of the large dams in the region were completed between 1968 and 1970 and 14\% between 1985 and 1993.

Figure 6: Locations of step changes in random-forest based streamflow reconstructions: positive shift in the mean (blue), negative shift in the mean (red). Stations are ordered by country (BF: Burkina Faso, BJ: Benin, CF: Central African 
Republic, CG: Democratic Republic of Congo, CI: Cote d'Ivoire, CM: Cameroon, GA: Gabon, GH: Ghana, GN: Guinea Conakry, ML: Mali, NG: Nigeria, SN: Senegal, TD: Chad, TO: Togo). The black curve on top presents the temporal distribution of change-points over the study area.

Gradual changes (trends) are investigated in mean annual reconstructed streamflow time series (MICE and RF) over the periods defined by the change-points analysis, which highlights two major discontinuities at the regional scale (1970 and 1993): 1950-1970 (wet conditions), 1970-1993 (drought conditions), 19932005 (partial recovery). Figure 7 presents the correlation between the results from both reconstruction methods for the different time intervals. Both reconstruction methods show similar streamflow trends at the regional scale (Figure 7). However, although the results from both methods remain significantly correlated $(p \leq 0.1)$, trends differ slightly in the post-1990 period, mainly due to the limited ability of MICE to extrapolate beyond the range of observed values, highlighting that hydrological regimes may have changed in the 1993-2005 period.

Figure 7: Spatial correlation between normalized trends calculated using both reconstructed datasets, for the three periods of investigation: 1950-1970 (red), 1970-1993 (green) and 1993-2005 (blue).

Trend analysis over the three different time intervals revealed that, during the 1950-1970 period, even though mean annual streamflow values are at the highest, streamflow trends are significantly negative (up to $-4 \%$ per year) over the Sahelian and Sudanian regions of West Africa (Figure 8a-b): this suggests that the step change observed around 1970 in this region was mainly induced by a gradual aridification pattern. During the same period, significant positive trends are identified over Central Africa (up to $+2.5 \%$ per year) (Figure $7 \mathrm{a}-\mathrm{b}$ ). At the regional scale, $35 \%$ and $30 \%$ of trends are significant for MICE and RF respectively. Among those significant trends, $52 \%$ and $40 \%$ are positive mainly in Sudanian and coastal regions (Figure 8a-b) for MICE and RF respectively. Most of the significant negative trends are in the Sahelian region, driven by dryer conditions in the end of the 1960s compared to the 1950s (Figure 8a-b).

These negative streamflow trends along the Sahelian band spread toward the Gulf of Guinea and over Central Africa during the well-known drought period of the 1970s and 1980s (Dai et al.,2004; Lebel, 2003; Nicholson, 2013; Figure 8c-d), marking a stronger spatial coherence. During this dry period, mean annual 
374

streamflow values decrease by up to $69 \%$ compared to the 1950 s and 1960 s. Also, more than $90 \%$ of all significant trends (40\% and 38\% using MICE and RF, respectively) are negative (up to $-5 \%$ per year), as a result of intensified dry conditions from the end of the 1960s (Figure 8c-d).

The last period (1993-2005) is characterized by a reduction in significant trends [MICE (26\%) and RF (8\%)] and contrasting patterns mainly due to the limited ability of MICE to fully capture complex streamflow interactions (Figure 8e-f). Compared to the previous period (1970-1993) mean annual streamflow values mark an increase of at least $15 \%$ over more than half of the study area and a decrease of around $7 \%$ in some regions (Figure 8c-f). Significant positive trends on the Niger River, as shown using RF, would however be consistent with the "Sahelian paradox" (Descroix et al., 2013; Mahé et al., 2005), with a higher flow contribution from the Sahelian tributaries. Despite positive rainfall trends in some Sudanian areas (Northern Ghana and Ivory Coast), which are detected using both MICE and RF, streamflow trends remain negative (Figure 8e-f). This might have resulted from severe groundwater depletion during the dry periods 1970s and 1980s (Mahé et al., 2005), but this needs further research.

Figure 8: Streamflow trends estimated for both reconstructed datasets, upward triangles for positive trends and downward triangles for negative trends, filling highlights the significance of trend at $10 \%$ (negative trends in red and positive trends in blue). River basins are greyed and the river network in blue.

\subsection{Observed climatic trends between 1950 and 2005}

\subsubsection{Trends in annual precipitations}

Annual rainfall trends for the 1950-1970 period decline by $\sim 10 \mathrm{~mm}$ yr-1 (significant for around $34 \%$ of the study area) along the entire Sahelian band, but locally increase in parts of the Central African Republic and Democratic Republic of Congo (Figure 9a). This suggests that the drying trends might have started earlier than hitherto recognized. The negative trends observed along the Sahelian band then spread towards the Gulf of Guinea during the 1970-1993 period (Figure 9b), similarly to the pattern observed in streamflow (Figure $8 \mathrm{c}-\mathrm{d}$ ). 
However, although this period is widely recognized to be extremely dry from comparisons of mean values, we find here that only $11.5 \%$ of the study area show significantly negative precipitation trends. Interestingly, however, significant positive trends are identified in the Congo River basin (Figure 9b). This highlights a potential hiatus in the regional drying trend during the 1970s and 1980s, supporting earlier studies (Le Barbé and Lebel, 1997; D’Amato and Lebel, 1998). These could result from increasing quasidecadal rainfall variability as suggested in Dieppois et al. $(2013,2015)$. In the post-1993 period, we note an increase of annual precipitation compared to the previous period (trends significant for $11 \%$ of the study area), corroborating previous findings (Biasutti, 2013; Lebel and Ali, 2009; Nicholson et al., 2000). This potential annual rainfall recovery $(\sim+11.5 \mathrm{~mm}$ yr-1) is particularly pronounced in western and eastern Sahel and Liberia (Figure 9c), which agrees with the findings of Ogungbenro and Morakinyo (2014) in northern Nigeria. At the same time, regions in northern Cameroon and in the Democratic Republic of Congo, are characterized by significant negative trends $(\sim-7 \mathrm{~mm} \mathrm{yr}-1$, to $\sim-30 \mathrm{~mm}$ yr-1), in agreement with the recent study of central African rainfall by Maidment et al. (2015).

The same analysis, conducted using the GPCC V7 datasets, show similar patterns. The relationships are, however, slightly more significant over the study area for the three periods $(35 \%, 11.43 \%$, and $14.65 \%$ for the 1950-1970, 1970-1993 and post-1993 periods, respectively; not shown). In addition, during the post1993 period, the GPCC V7 dataset underlines a significant decreasing trend in Guinea (which, interestingly, does not appear in the CRU dataset) and a wider spatial extent of negative trends in Cameroon and Central African Republic. Despite these slight differences probably resulting from the greater number of observation stations used to generate the GPCC V7 dataset, agreement between precipitation and streamflow trends remains strong.

Overall, there is a good agreement between annual streamflow and precipitation trends over the entire study area highlighting the importance of precipitation in driving hydrological systems. However, quantifying runoff response to increasing precipitation is likely to be a complex task since rising temperatures and potential evapotranspiration could offset increasing precipitation. This issue is addressed in the following 
section by investigating trends in temperatures and potential evapotranspiration and their impact on runoff responses.

\subsubsection{Trends in mean annual minimum and maximum temperatures, and potential evapotranspiration}

As widely accepted, temperatures over the African continent have been increasing during the $20^{\text {th }}$ century (since 1950), and this is primarily associated with anthropogenic causes (e.g. IPCC, 2014; Stott et al., 2010). However, here we aim to discuss temperature trends in term of impact on water resources, through its impact on evapotranspiration and effective rainfall.

Trends in annual minimum and maximum temperatures over the study area show different amplitude and spatial extents. For instance, in West and Central Africa, the 1950-1970 period is characterized by positive trends $\left(+0.5\right.$ to $\left.+1.5^{\circ} \mathrm{C}\right)$ in minimum annual temperatures (significant for $32.5 \%$ of the study area). However, weaker and spatially less coherent trends are detected for annual maximum temperatures $(\sim$ $+0.5^{\circ} \mathrm{C}$; significant for $9.5 \%$ of the study area). Maximum values are reported only in the western Sahel (Figure 9d, g). The rest of the study area shows few significant trends, apart from some significant negative trends in both minimum and maximum annual temperatures (Figure 9d, g). According to the CRU potential evapotranspiration estimates, the patterns in both minimum and maximum temperatures could have resulted in significant positive evapotranspiration trends $(\sim+2.5 \mathrm{~mm} \mathrm{yr}-1)$ in western and central Sahel, and significant decreasing trends ( -3.75 mm yr-1) over the Gulf of Guinea and Central Africa regions (Figure $9 \mathrm{j})$.

The 1970-1993 period is marked by a homogeneous increase in annual minimum temperatures, which is significant over $63 \%$ of the study area (including regions in the Congo River basin, where significant cooling is identified; Figure 9e). These trends contrast with annual maximum trends, which are negative in the Sahelian region $\left(\sim-1^{\circ} \mathrm{C}\right)$, but positive in the Gulf of Guinea coastal regions and Central Africa (Figure 9h). This configuration is, however, consistent with a weaker meridional thermal gradient, which characterizes a southward shift of the ITCZ and dry conditions in the Sahel (Chiang and Friedman, 2012; 
Webster et al., 1998). The fluctuation of temperature range during this period has driven a uniform decrease in potential evapotranspiration over the Sahelian band but increased significant positive trends in the Gulf of Guinea and Central Africa (Figure 9k).

Since 1993, greater spatial coherence emerges, with increasing trends of both annual minimum temperatures (significant for $65 \%$ of the study area) and maximum temperatures (significant for $85 \%$ of the study area; Figure 9f, i). Trends in annual maximum temperatures, however, are more pronounced $\left(\sim 0.1^{\circ} \mathrm{C}\right.$ higher in average) than in annual minimal temperature (Figure 9i). This could be an artefact of the baseline period used in our study, as this result contrasts with those revealed in some other studies (e.g. Funk et al., 2012; Ringard et al., 2016), which suggested that minimum temperatures have risen faster compared to maximum temperatures in the post-1990 period. Nonetheless, temperature trends are consistent with trends in potential evapotranspiration (Figure 91), which highlight a uniformly significant (for around $46.8 \%$ of the study area) and positive trend $(\sim<3.8 \mathrm{~mm}$ yr-1) over almost the entire eastern part of the study region. Regions in western, eastern Sahel and part of the Gulf of Guinea, however, show non-significant negative trends (Figure 91), which may result from the spurious trends (above) in minimum temperatures and errors resulting from the use of the same monthly wind speed values (1961-1990) for each year.

Trends in effective rainfall, approximated here as the difference between rainfall totals and potential evapotranspiration are presented in Figure 9m-o. Over the two first periods (1950-1970 and 1970-1993), these trends are similar to precipitation trends: this suggests the limited effect of potential evapotranspiration on the relationship between rainfall and streamflow (Figure 9m-n). However, from 1993, the situation is reversed, mainly in the eastern part of the Sahel (eastern Niger, Chad and northern Nigeria), where high potential evapotranspiration rates significantly subdue the potential impact of the rainfall recovery (Figure 9o) on streamflow. This might help explain, at least partially, why the rainfall recovery over these regions is not associated with significant positive streamflow trends (Figure 8c-d). Over Central Africa (areas in the Congo basin), it also appears from trends in effective rainfall that during 
recent decades, the decrease in rainfall is exacerbated by increased evapotranspiration (Figure 9c, $\mathrm{i}$, o). This suggests enhanced climatic stress on Central African streamflow in relation to warming temperatures.

Figure 9: Hydroclimatic trends over the study area for three different time intervals (1950-1970, 1970-1993 and 19932005) according to the CRU.TS. V4.00 dataset: a-c) Annual precipitation trends d-f) Minimum annual temperature trends g-i) Maximum annual temperature trends j-l) Annual potential evapotranspiration trends m-o) Annual effective rainfall trends. Sen's slope values are displayed through a red-white-blue color scale. Solid red lines highlight trend significance at $p \leq 0.1$ according to a modified MK trend test accounting for serial correlation in the time series.

\subsection{Precipitation and streamflow variability}

Standard trend analysis methods assess the slope of the considered variables over the period of investigation. The value of the slope is, however, highly dependent on the selected time window and changes significantly for different start and end dates, mainly because of internal variability. Such limitations are tackled in the multitemporal trend analysis method (Liebmann et al.,2010; McCabe and Wolock, 2002). We used the Liebmann et al. (2010) approach, to calculate precipitation and streamflow trends for all possible segments of 5 to 56 years between 1950 and 2005 . The results are stored in twodimensional diagrams (e.g. Figure 11), which have been analyzed using multiscale bootstrapped agglomerative hierarchical clustering.

Clustering streamflow variability diagrams resulted in three main clusters, which are highly significant $(p \leq$ 0.1) based on the multiscale bootstrapping test, with associated spatial distributions presented in Figure 10, identified using hierarchical clustering.

Figure 10: Spatial distribution of streamflow variability (1950-2005) clusters based on multi-temporal trend analysis superimposed on the river network (blue) and major river basins (grey shaded). All the clusters are highly significant at p $\leq 0.1$ according to the multiscale bootstrapping test. Different colours displayed the location of the different clusters.

Overall, these three clusters show decreasing flow trends over the entire period (1950-2005), but we also identify decadal periods of alternating positive and negative trends with different amplitudes, modulating the general trend, according to the three clusters (Figure 11). For instance, a pronounced positive trend in the mid-1970s during the drought period emerges in cluster 1 (Congo Basin at Brazzaville), which 
progressively disappears in cluster 2 (lower Niger River, Benue and stations in the upper Congo basin) and cluster 3 (all the other stations; Figure 11). This emphasizes the importance of decadal variability in modulating streamflow trends (which has hitherto been little studied) and provides a new picture of the behaviour of hydrological systems in West and Central Africa.

These differences in the contribution of interannual to decadal variability could, however, arise from differences in the large-scale climate drivers. According to Mahé et al. (2013), Cluster 1, which is located at the outlet of the Congo Basin at Brazzaville, could be more sensitive to changes in the thermal gradient between the Atlantic and Indian oceans resulting in a unique runoff variability. Such decadal fluctuations have also been reported for eastern Sahel rainfall in Dieppois et al. (2013, 2015), suggesting that differences between clusters should at least partly be related to different interactions with catchment properties (e.g. reduction in soil water holding capacity) and water management. In addition, while trend amplitude is a distinctive element between clusters, the sign and temporal scale during the humid period (1950-1960) and the recovery period (post-1990) are also very important. For instance, stations in clusters 1 and 2 are characterized by wet conditions in the 1950s-1960s, whereas most of the stations in cluster 3 show decreasing trends during the same period (Figure 11). Furthermore, cluster 3 highlights less intense dry conditions in the 1980 s and a more pronounced recovery in the recent years compared to the first two clusters (Figure 11). A further classification of the stations in cluster 3 is provided as supplementary materials. The significant negative trend (observed in the 1980s) in stations of cluster 2, for instance might have been partly accentuated by large dams in Nigeria (e.g. the Dadin Kowa Dam and the Kiri dam, on a main tributary of the Benue river).

Figure 11: Multi-temporal diagrams of the different cluster centroids: trends in $\mathbf{m}^{3} / \mathrm{s}$ are presented in red (negative) white (null) - blue (positive) colour scale, contours lines represent trend significance at $p \leq 0.1$.

Applying the same clustering method to gridded annual rainfall, variability diagrams resulted in 12 major clusters $(p \leq 0.1)$ and few grid points with lower probabilities $(p \leq 0.2)$ and therefore unclassified (Figure 12). 
Figure 12: Clusters of rainfall variability generated using CRU TS V4.00 $\left(2.5^{\circ} \times 2.5^{\circ}\right)$ on the period $1950-2005$ : colours and numbers from 1 to 12 refer to the grid points within the 12 initial clusters at $p \leq 0.1$. Red boxes represent grid points which did not fall within the clusters. All the clusters are highly significant at $p \leq 0.1$ according to the multiscale bootstrapping test.

West African regions predominantly fall within clusters 11, 8, 2 and 1 (Figures 12, 13) which are mainly characterized by persistent dry conditions from the end of the 1960s, and positive trends starting earlier in clusters 2 and 8 (1970s) compared to clusters 1 and 11 (end of 1980s). Comparing, for instance, patterns observed in streamflow cluster 3 and rainfall cluster 11, it appears that the significant negative rainfall trend in the 1980s is attenuated in the streamflow signal and, furthermore, the observed streamflow recovery is more widespread compared to the recovery observed in rainfall. This suggests a combination of drivers which might have enhanced the runoff response, described by some authors as the "Sahelian paradox" (Descroix et al., 2013; Mahé et al., 2005) which refers to a counterintuitive increase in runoff coefficient despite decreasing rainfall. In fact, parts of this region are known to have experienced drastic changes in land cover resulting from several coupled interactions between increasing cultivated areas (Cappelaere $e t$ al.,2009), and natural vegetation changes after the 1970s and 1980s major drought periods (Gal et al., 2017).

The clustering underlines a high variability in rainfall over the western part of West Africa, where some grid points are left outside the clusters. Some parts of this region are characterized by the pattern observed in cluster 9 (Figures 12-13). After the humid period of the 1960s, rainfall is characterized by decreasing trends until the 1990s (Figure 13). From the end of the 1990s rainfalls largely returned to their level of the 1960 s as a result of a recovery which started in the 1980s (Figure 13). From these different clusters, it appears that most regions over western Africa have experienced improved streamflow conditions because of the recent rainfall recovery even though long-term trends remain negative.

Over Central Africa, rainfall shows high decadal variability (succession of wet and dry periods) with no clear long-term trends (clusters 4, 5, 6, 10 and 12; Figure 13). This region is characterized by a humid 
period from the mid-1950s to the 1970s, with dry episodes around 1980 (Figure 13). In cluster 4, for instance, recent conditions (1990s-2000s) are almost as wet as the humid period, which is not the case for cluster 6 where recent conditions remain relatively drier (Figure 13). The streamflow variability displayed in cluster 1 (Congo basin at Brazzaville) appears to have resulted from a combination of rainfall clusters 6, 10 and 12, highlighting the diverse climatic influences in this basin (Figure 11-13). Rainfall-runoff relations over this region suggest that rainfall is the main driving factor, with no, or limited, effect from other moderating factors (e.g. land use change, intensification of agriculture, deforestation, and warming temperatures). The change in seasonal rainfall distribution may likely be the major factor related to climatic change in this area to have an impact on discharges' seasonal regimes. This can be observed at the scale of small basins like the Kienke at Kribi in the South coastal Cameroon, where the small dry season disappeared during the last decades (Lienou et al., 2008), and at the larger scale for the Ogooue river in Gabon, where the Spring flood lost $30 \%$ of discharge value after the rainfall regimes slightly changed over past decades (Mahé et al., 2013), the same being observed to a lesser extent for the whole Congo basin (Alsdorf et al., 2016; Tshimanga et al., 2016).

Figure 13: Multi-temporal diagrams of the 12 rainfall variability clusters derived from the multi-scale bootstrap clustering: trends (mm) are presented in red (negative) - white (null) - blue (positive) color scale, contours lines represent trend significance at $p \leq 0.1$.

\section{CONCLUSION}

Using parametric (MICE) and non-parametric (RF) gap filling methods, a new and complete streamflow dataset, spatially distributed over West and Central Africa and encompassing different climatic zones and hydrological regimes has been generated. Gap filling results highlighted that both methods performed well, though, in general, MICE was slightly outperforming RF. However, due to its parametric nature, MICE analyses, in some cases, failed to capture changes in streamflow conditions (case of Niamey on the Niger River). The complete streamflow dataset (RF method) was then used to investigate streamflow changes and variability and their interactions with key climatic variables (P, T, PET) over West and Central Africa 
between 1950 and 2005 .

Majority of streamflow stations over the study area present a step change in 1970 mainly induced by a gradual aridification pattern. In the 1990s a positive shift in mean discharge is observed, but it is difficult to conclude whether this change is led by positive rainfall trends or single wet episodes amplified by land use change, warming temperature and evapotranspiration reduction. In general, there is a good agreement between streamflow and precipitation trends, with an offsetting effect of potential evapotranspiration observed in some regions. Over the study area, the period 1950-1970 was characterized by negative streamflow trends in Sahelian and Sudanian regions of West Africa, which seems counterintuitive considering that this period was the wettest on record. The opposite is observed over Central Africa where significant positive streamflow trends emerge. The following period (1970-1993), is marked mostly by negative trends due to dryer conditions. This pattern is reversed during the 13-year period 1993-2005, with mainly positive trends resulting from increased rainfall and changes in land use in Sahelian regions. Annual streamflow trends reflect annual precipitation trends which decrease from the 1950 s to 1980 s and increase from the 1990s. More importantly, the study showed that, even though the 1950s and 1960s were the wettest decades in terms of total rainfall amounts, decreasing annual rainfall trends were more prominent, suggesting an earlier start of the drought. The drought peaked during the $1970 \mathrm{~s} / 80 \mathrm{~s}$, over most of western Africa, but the reduced negative trends in precipitation suggest a hiatus, which have resulted from quasidecadal variability.

Furthermore, over most of the study area, hydrological regimes during the recent period have been impacted by the rainfall recovery which is not limited to the west African Sahel. Even though other climatic variables such as wind speed and vapor pressure deficit might have played an important role, temperature trends appeared to be highly related to trends in potential evapotranspiration, which seem to have hampered the effect of the rainfall recovery on hydrological regimes in some areas over the eastern Sahel (eastern Niger, Chad and northern Nigeria).

Building significantly on previous studies, which generally provide trend estimates over a certain period, 
we have provided novel information and analyses of the impact of internal variability using the multitemporal trend analysis method. The results highlight strong interannual to decadal signals which clearly modulate streamflow and precipitation trends. In West Africa, for instance, the 1970-1989 period is characterized by two main dry events (1972-1973 and 1983-1984) separated by a wet period (Nicholson et al., 2000; Dai et al., 2004). This probably resulted in increased runoff coefficients in Sahelian catchments, as observed by Albergel (1987) in Burkina Faso over the period (1969-1984) and later in larger Sahelian catchments (Descroix et al., 2013; Mahé et al., 2005). Such a rainfall-runoff response (referred to as the Sahelian paradox) indeed seems paradoxical when considering long-term trends but becomes less counterintuitive when investigating variability in precipitation and streamflow time series. Therefore, rather than describing the "Sahelian paradox" as an increase in runoff despite reduced rainfall since 1970, it should be considered as enhancing runoff response to positive rainfall anomalies, as a result of changes in land-surface properties.

If flow trends can be largely explained by decadal variability in rainfall (Dieppois et al., 2013), influence of other driving factors should also be considered at the catchment level (such as geology, soils, agricultural land use change, water consumption and urbanization). For instance, large dams constructed in the 1980s in Nigeria (e.g. the Dadin Kowa Dam and the Kiri dam, on a main tributary of the Benue river), might have affected to some extent the variability of the lower Niger river, but this is beyond the scope of the present paper.

This study has shed light on hydroclimatic variability and its associated impact on streamflow regimes over large, key parts of West and Central Africa over recent decades, and also provides water practitioners with reconstructed streamflow time series which can be used as input for water balance models to develop sound water and agricultural management policies. These useful time series here can form the basis of future developments, to include updating of the streamflow datasets through national water offices. This should further improve the quality of the reconstructions and open up investigations of more recent conditions. In addition, future in-depth studies are required of climate processes (e.g. sea-surface temperature, 
623 atmospheric circulation), catchment land use properties, and water management policies, all of which can

624 drive streamflow variability at interannual to decadal timescales. As these potentially modulate the climate 625 signal, such work is required to further improve our understanding of hydrological variability in West and 626 Central Africa, and our ability to model hydrological changes in this region.

\section{Acknowledgements}

628 We acknowledge the HydroSciences Montpellier Laboratory, particularly Nathalie Rouché for providing us 629 with streamflow datasets used in this study. Moussa gratefully acknowledges the funding received towards 630 his $\mathrm{PhD}$ studies from Coventry University, UK, and resources provided by the Centre for Agroecology, 631 Water and Resilience (CAWR). We thank the anonymous reviewers for their insightful comments and 632 suggestions.

\section{Appendix A: List of reconstructed streamflow time series}

\begin{tabular}{|l|l|l|l|l|}
\hline ID & Basin & Station name & latitude & Longitude \\
\hline BFQ0010 & LERABA & YENDERE au pont & 10.1667 & -5.0683 \\
\hline BFQ0060 & VOLTA & WAYEN & 12.3789 & -1.08 \\
\hline BFQ0064 & VOLTA & BOROMO & 11.7833 & -2.9167 \\
\hline BFQ0065 & VOLTA & DAPOLA & 10.5667 & -2.9167 \\
\hline BFQ0072 & VOLTA & NWOKUY & 12.5278 & -3.55 \\
\hline BFQ0074 & VOLTA & SAMANDENI & 11.4667 & -4.4667 \\
\hline BJQ0009 & SOTA & COUBERI & 11.74 & 3.3333 \\
\hline BJQ0022 & COUFFO & LANHOUNTA - LANTA & 7.1 & 1.8833 \\
\hline BJQ0028 & MONO & ATHIEME & 6.9167 & 1.6667 \\
\hline BJQ0033 & OUEME & BONOU & 6.9 & 2.45 \\
\hline BJQ0036 & OUEME & HETIN SOTA & 6.6 & 2.5 \\
\hline BJQ0047 & OKPARA & KABOUA & 8.25 & 2.7167 \\
\hline BJQ0050 & SOTA & RTE KANDI-SEGBANA AMONT & 10.9833 & 3.25 \\
\hline BJQ0075 & WE-WE & WE-WE & 9.1667 & 2.1083 \\
\hline BJQ1000 & PENDJARI & PORGA & 10.99401 & 0.9773 \\
\hline BJQ2000 & NIGER & MALANVILLE & 11.888 & 3.383 \\
\hline BJQ2004 & OUEME & PONT DE BETEROU & 9.199179 & 2.267582 \\
\hline BJQ2005 & OUEME & PONT DE SAVE & 8 & 2.4167 \\
\hline BJQ2006 & ZOU & ATCHERIGBE & 7.5333 & 2.0333 \\
\hline CFQ0005 & OUHAM & BOSSANGOA & 6.4667 & 17.45 \\
\hline CFQ0025 & OUBANGUI & ZINGA TRANSIT & 3.713833 & 18.58716 \\
\hline CFQ0027 & MBOMOU & ZEMIO & 5.028726 & 25.1471 \\
\hline CFQ0028 & BANGUI-KETTE & ALINDAO & 5.04457 & 21.20172 \\
\hline
\end{tabular}




\begin{tabular}{|c|c|c|c|c|}
\hline CFQ0034 & LOBAYE & M'BATA & 3.666296 & 21.98114 \\
\hline CFQ0040 & M'POKO & BOSSELE-BALI & 4.530737 & 18.46878 \\
\hline CFQ0057 & SANGHA & SALO & 3.181621 & 16.11362 \\
\hline CFQ2000 & OUBANGUI & BANGUI & 4.364275 & 18.59487 \\
\hline CGQ0003 & ALIMA & TCHIKAPIKA & -1.26385 & 16.16937 \\
\hline CGQ0013 & LEFINI & BWEMBE & -2.9167 & 15.6308 \\
\hline CGQ0014 & LIKOUALA & ETOUMBI & 0.0167 & 14.95 \\
\hline CGQ0015 & LIKOUALA & MAKOUA & 0.00167 & 15.633 \\
\hline CGQ0017 & N'KENI & GAMBOMA & -1.9 & 15.85 \\
\hline CGQ0020 & KOUYOU & LINNEGUE & -0.5 & 15.9333 \\
\hline CGQ0026 & LIKOUALA & BOTOUALI & -0.55 & 17.45 \\
\hline CGQ2000 & CONGO & BEACH - V.N. Brazzaville & -4.27285 & 15.29392 \\
\hline CGQ2001 & SANGHA & OUESSO & 1.6167 & 16.05 \\
\hline ClQ0007 & BANDAMA & MBRIMBO & 6.0125 & -4.425 \\
\hline CIQ0013 & BANDAMA & KIMOUKRO BALISE 10201 & 6.5056 & -5.3053 \\
\hline CIQ0032 & MARAOUE & RTE BEOUMI-SEGUELA - KONGASSO 10145 & 7.8319 & -6.2542 \\
\hline CIQ0033 & MARAOUE & BOUAFLE $\quad 10147$ & 6.979988 & -5.75437 \\
\hline $\mathrm{ClQ} 0058$ & $\mathrm{NZI}$ & BOCANDA & 7.0442 & -4.52 \\
\hline CIQ0061 & $\mathrm{NZI}$ & DIMBOKRO 10141 & 6.6358 & -4.71 \\
\hline CIQ0154 & KOUROUKELE & IRADOUGOU & 9.7069 & -7.8028 \\
\hline CIQ0292 & KAVI & MBESSE & 5.8386 & -4.2961 \\
\hline CIQ0312 & CAVALLY & FLAMPLEU & 7.2833 & -8.0583 \\
\hline CIQ0314 & CAVALLY & TAl & 5.86 & -7.45 \\
\hline CIQ0319 & NSE & TAI 1 (TAI PONT) & 5.875 & -7.4583 \\
\hline CIQ4020 & BANDAMA & BADA & 8.1069 & -5.4972 \\
\hline $\mathrm{ClQ} 4022$ & BANDAMA & TIASSALE $\quad 10144$ & 5.8947 & -4.8178 \\
\hline CIQ4025 & $\mathrm{NZI}$ & FETEKRO & 7.8106 & -4.6875 \\
\hline CIQ4026 & $\mathrm{NZI}$ & MBAHIAKRO 10133 & 7.4458 & -4.3556 \\
\hline CIQ4027 & $\mathrm{NZI}$ & NZIENOA 10136 & 5.9964 & -4.8125 \\
\hline CIQ4028 & COMOE & ANIASSUE PONT 10138 & 6.6375 & -3.7126 \\
\hline CIQ4029 & COMOE & MBASSO & 6.125 & -3.48 \\
\hline CIQ4030 & COMOE & SEREBOU & 7.9383 & -3.9419 \\
\hline CIQ4031 & SASSANDRA & SEMIEN & 7.7083 & -7.0669 \\
\hline CIQ4032 & SASSANDRA & SOUBRE & 5.7833 & -6.6131 \\
\hline ClQ4033 & BAFING & BAFINGDALA (BADALA) BIANKOUMA 10162 & 7.841611 & -7.66658 \\
\hline CIQ4034 & LOBO & NIBEHIBE (NIBEIGBEU) & 6.8003 & -6.7 \\
\hline CIQ4035 & COMOE & AKAKOMOEKRO 10149 & 7.447418 & -3.5094 \\
\hline CMQ0008 & DOUME & DOUME & 4.2333 & 13.45 \\
\hline CMQ0029 & SANAGA & NACHTIGAL & 4.35 & 11.6333 \\
\hline CMQ0030 & SANAGA & NANGA EBOKO & 4.7 & 12.3833 \\
\hline CMQ0038 & MBAM & BAC DE GOURA & 4.5667 & 11.3667 \\
\hline CMQ0071 & NYONG & DEHANE & 3.5667 & 10.1167 \\
\hline CMQ5001 & VINA NORD & PONT DE BEREM & 7.55 & 13.95 \\
\hline CMQ5005 & DJA & SOMALOMO & 3.3667 & 12.7333 \\
\hline
\end{tabular}




\begin{tabular}{|c|c|c|c|c|}
\hline CMQ5006 & BENOUE & BUFFLE NOIR & 8.1167 & 13.8333 \\
\hline CMQ5007 & BENOUE & GAROUA & 9.294019 & 13.4041 \\
\hline CMQ5015 & MAPE & AU PONT DE MAGBA AMONT & 5.9833 & 11.2667 \\
\hline CMQ5016 & VINA DU SUD & LAHORE & 7.25 & 13.5667 \\
\hline CMQ5018 & LOBE & BAC KRIBI-CAMPO & 2.8667 & 9.8833 \\
\hline CMQ5019 & LOKOUNDJE & LOLODORF & 3.2333 & 10.7333 \\
\hline CMQ5038 & MUNGO & MUNDAME & 4.5667 & 9.5333 \\
\hline CMQ5040 & NTEM & BAC DE NGOAZIK & 2.1333 & 11.3 \\
\hline CMQ5044 & LOM & BETARE OYA & 5.9167 & 14.1333 \\
\hline CMQ5047 & KIENKE & KRIBI SCIERIE & 2.9333 & 9.9 \\
\hline CMQ5050 & KADEI & BATOURI & 4.4167 & 14.3167 \\
\hline GAQ0006 & OGOOUE & BOOUE (LMNG) & -0.1025 & 11.9367 \\
\hline GAQ0015 & OGOOUE & NDJOLE OPERATIONNEL & -0.455 & 10.4025 \\
\hline GAQ0028 & IVINDO & MAKOKOU (LMNG) & 0.5689 & 12.8611 \\
\hline GAQ0041 & NGOUNIE & FOUGAMOU SHO (LMNG) & -1.2156 & 10.5908 \\
\hline GAQ0046 & NGOUNIE & MOUILA VAL MARIE & -1.8869 & 11.0558 \\
\hline GHQ0045 & NASIA & NASIA & 10.15 & -0.8 \\
\hline GHQ1005 & VOLTA NOIRE & BUI AMONT & 8.2833 & -2.2333 \\
\hline GNQ0015 & NIGER & FARANAH & 10.03744 & -10.7495 \\
\hline GNQ0016 & NIGER & KOUROUSSA & 10.65169 & -9.87096 \\
\hline GNQ0018 & NIGER & TIGUIBERY (Siguiri) & 11.3545 & -9.16459 \\
\hline GNQ0026 & MILO & KANKAN & 10.3833 & -9.3 \\
\hline GNQ0030 & NIANDAN & BARO & 10.6167 & -9.7 \\
\hline GNQ0034 & NIANDAN & KISSIDOUGOU (NIANDAN SCIERIE) & 9.25 & -10.0167 \\
\hline GNQ0200 & BADI & BAC DE BADI & 10.2833 & -13.4 \\
\hline GNQ0204 & KONKOURE & PONT DE LINSAN & 10.3 & -12.4167 \\
\hline MLQ0009 & NIGER & DIRE & 16.27595 & -3.395 \\
\hline MLQ0012 & NIGER & KE MACINA & 13.95831 & -5.35896 \\
\hline MLQ0019 & NIGER & KOULIKORO & 12.85727 & -7.55811 \\
\hline MLQ0022 & NIGER & MOPTI & 14.49605 & -4.20127 \\
\hline MLQ0036 & NIGER & TOSSAYE & 16.9333 & -0.5833 \\
\hline MLQ0052 & DIAKA & KARA & 14.1667 & -5.0167 \\
\hline MLQ0091 & BANI & SOFARA & 14.01393 & -4.2429 \\
\hline MLQ0123 & SENEGAL & GALOUGO & 13.8333 & -11.1333 \\
\hline MLQ0130 & SENEGAL & BAFING MAKANA & 12.55 & -10.2667 \\
\hline MLQ0131 & SENEGAL & SOUKOUTALI & 13.2 & -10.4167 \\
\hline MLQ0134 & BAKOYE & OUALIA & 13.6 & -10.3833 \\
\hline MLQ0135 & BAKOYE & тоUкото & 13.45 & -9.8833 \\
\hline MLQ0137 & FALEME & FADOUGOU & 12.5167 & -11.3833 \\
\hline MLQ0145 & BAOULE & SIRAMAKANA (Balenda) & 13.5833 & -9.8833 \\
\hline MLQ2003 & NIGER & KENIEROBA & 12.1 & -8.3167 \\
\hline MLQ2007 & SANKARANI & SELINGUE & 11.5833 & -8.1667 \\
\hline MLQ2008 & BANI & DOUNA & 13.21385 & -5.90311 \\
\hline MLQ2064 & SENEGAL & DAKA SAIDOU & 11.95 & -10.6167 \\
\hline
\end{tabular}




\begin{tabular}{|c|c|c|c|c|}
\hline MLQ2066 & SENEGAL & DIBIA & 13.2333 & -10.8 \\
\hline MLQ2069 & FALEME & GOURBASSY & 13.4 & -11.6333 \\
\hline MLQ2070 & SENEGAL & KAYES & 14.45 & -11.45 \\
\hline NEQ2000 & NIGER & NIAMEY & 13.5016 & 2.105 \\
\hline NGQ0001 & BENUE & MAKURDI & 7.75 & 8.5333 \\
\hline NGQ0002 & NIGER & ONITSHA & 6.166667 & 6.75 \\
\hline NGQ2000 & NIGER & LOKOJA & 7.8 & 6.7667 \\
\hline NGQ2004 & NIGER & IDAH & 7.1 & 6.716667 \\
\hline SNQ2039 & GAMBIE & KEDOUGOU & 12.55 & -12.1833 \\
\hline SNQ2045 & GAMBIE & MAKO & 12.8667 & -12.35 \\
\hline SNQ2055 & GAMBIE & SIMENTI & 13.0333 & -13.3 \\
\hline SNQ2060 & GAMBIE & WASSADOU-AMONT & 13.35 & -13.3667 \\
\hline SNQ2062 & GAMBIE & WASSADOU-AVAL & 13.35 & -13.3833 \\
\hline SNQ2063 & SENEGAL & BAKEL & 14.9 & -12.45 \\
\hline SNQ2064 & SENEGAL & DAGANA & 16.5167 & -15.5 \\
\hline SNQ2065 & FALEME & KIDIRA UHEA & 14.45466 & -12.205 \\
\hline SNQ2066 & SENEGAL & MATAM & 15.65 & -13.25 \\
\hline SNQ2067 & DOUE & NGOUI & 16.15 & -13.9167 \\
\hline SNQ2068 & SENEGAL & SALDE & 16.16325 & -13.8795 \\
\hline TDQ0004 & CHARI & SARH (EX.FORT-ARCHAMBAULT) & 9.15 & 18.4167 \\
\hline TDQ0009 & CHARI & MAILAO & 11.6 & 15.2833 \\
\hline TDQ0013 & BAHR-SARA & MANDA & 9.1833 & 18.2 \\
\hline TDQ0014 & BAHR-SARA & MOISSALA & 8.3333 & 17.7667 \\
\hline TDQ0036 & LIM & OULI BANGALA & 7.8333 & 15.8333 \\
\hline TDQ0041 & PENDE & GORE & 7.95 & 16.6167 \\
\hline TDQ0043 & TANDJILE & TCHOA & 9.3333 & 16.0833 \\
\hline TDQ2011 & CHARI & BOUSSO & 10.5 & 16.7167 \\
\hline TDQ5004 & LOGONE & KATOA & 10.8333 & 15.0833 \\
\hline TDQ5005 & LOGONE & LAI (MISSION) & 9.4 & 16.3 \\
\hline TDQ5006 & LOGONE & LOGONE-GANA & 11.55 & 15.15 \\
\hline TOQ0006 & KARA & LAMA KARA 1 & 9.5333 & 1.1833 \\
\hline TOQ0037 & SIO & KPEDJI & 6.5317 & 1.0083 \\
\hline TOQ0042 & MONO & CORREKOPE & 7.8 & 1.3 \\
\hline TOQ0043 & MONO & DOTAIKOPE & 7.8167 & 1.2667 \\
\hline TOQ0046 & MONO & TETETOU & 7.0167 & 1.5333 \\
\hline TOQ0048 & AMOU & AMOU OBLO & 7.4 & 0.8667 \\
\hline TOQ0053 & ANIE & PONT CF T & 7.7333 & 1.2 \\
\hline TOQ0056 & KOLOWARE & KOLOWARE & 8.9667 & 1.2833 \\
\hline TOQ0057 & NA & PARATAO & 8.95 & 1.1833 \\
\hline TOQ0059 & OGOU & SIRKA & 7.9167 & 1.3667 \\
\hline
\end{tabular}

\section{REFERENCES}

636 Adeaga, O., Mahé, G., Dieulin, C., Elbaz-Poulichet, F., Rouche, N., Seide, J. L., \& Servat, E., 2012. Rainfall-Runoff 
Simulation in Part of Lower Niger Basin. Journal of Environmental Science and Engineering. B, 1(6B), 812.

Albergel, J., 1987. Sécheresse, désertification et ressources en eau de surface : application aux petits bassins du Burkina Faso. The influence of climate change and climatic variability on the hydrologic regime and water resources, 168, 355-365.

Ali, A., Lebel, T., 2009. The Sahelian standardized rainfall index revisited. Int. J. Climatol. 29, 1705-1714. https://doi.org/10.1002/joc. 1832

Alsdorf, D., Beighley, E., Laraque, A., Lee, H., Tshimanga, R., O’Loughlin, F., Mahé, G., Dinga, B., Moukandi, G., Spencer, R.G.M., 2016. Opportunities for hydrologic research in the Congo Basin. Rev. Geophys. https://doi.org/10.1002/2016RG000517

Amogu, O., Descroix, L., Yéro, K.S., Le Breton, E., Mamadou, I., Ali, A., Vischel, T., Bader, J.-C., Moussa, I.B., Gautier, E., Boubkraoui, S., Belleudy, P., 2010. Increasing River Flows in the Sahel? Water 2, 170-199. https://doi.org/10.3390/w2020170

Auger, I.E., Lawrence, C.E., 1989. Algorithms for the optimal identification of segment neighborhoods. Bull. Math. Biol. 51, 39-54. https://doi.org/10.1007/BF02458835

Badr, H.S., Dezfuli, A.K., Zaitchik, B.F., PETers-Lidard, C.D., 2016. Regionalizing Africa: Patterns of precipitation variability in observations and global climate models. J. Clim. 29, 9027-9043. https://doi.org/10.1175/JCLI-D-16$\underline{0182.1}$

Biasutti, M., 2013. Forced Sahel rainfall trends in the CMIP5 archive. J. Geophys. Res. Atmos. 118, 1613-1623. https://doi.org/10.1002/igrd.50206

Boyer, J. F., Dieulin, C., Rouche, N., Cres, A., Servat, E., Paturel, J. E., Mahé, G., 2006. SIEREM: An environmental information system for water resources. Climate Variability and Change-Hydrological Impacts, S. Demuth et al., Eds., IAHS Publication 308, IAHS/AISH, 19-25

Breiman, L., 2001. Random Forests. Mach. Learn. 45, 5-32. https://doi.org/10.1023/A:1010933404324

Cappelaere, B., Descroix, L., Lebel, T., Boulain, N., Ramier, D., Laurent, J.P., Favreau, G., Boubkraoui, S., Boucher, M., Bouzou Moussa, I., Chaffard, V., Hiernaux, P., Issoufou, H.B.A., Le Breton, E., Mamadou, I., Nazoumou, Y., Oi, M., Ottlé, C., Quantin, G., 2009. The AMMA-CATCH experiment in the cultivated Sahelian area of south-west Niger Investigating water cycle response to a fluctuating climate and changing environment. J. Hydrol. 375, 34-51. https://doi.org/10.1016/i.jhydrol.2009.06.021

Charrad, M., Ghazzali, N., Boiteau, V., Niknafs, A., 2014. NbClust: An $R$ Package for Determining the Relevant Number of Clusters in a Dataset. J. Stat. Softw. 61. https://doi.org/10.18637/iss.v061.i06

Chiang, J.C.H., Friedman, A.R., 2012. Extratropical Cooling, Interhemispheric Thermal Gradients, and Tropical Climate Change. Annu. Rev. Earth Planet. Sci. 40, 383-412. https://doi.org/10.1146/annurev-earth-042711-105545

D'amato, N., Lebel, T., 1998. On the characteristics of the rainfall events in the Sahel with a view to the analysis of climatic variability. Int. J. Climatol. 18, 955-974. https://doi.org/10.1002/(SICl)1097-0088(199807)18:9<955::AIDJOC236>3.0.CO;2-6

Dai, A., Lamb, P.J., Trenberth, K.E., Hulme, M., Jones, P.D., Xie, P., 2004. The recent Sahel drought is real. Int. J. Climatol. 24, 1323-1331. https://doi.org/10.1002/joc.1083

Descroix, L., Mahé, G., Lebel, T., Favreau, G., Galle, S., Gautier, E., Olivry, J.C., Albergel, J., Amogu, O., Cappelaere, B., Dessouassi, R., Diedhiou, A., Le Breton, E., Mamadou, I., Sighomnou, D., 2009. Spatio-temporal variability of hydrological regimes around the boundaries between Sahelian and Sudanian areas of West Africa: A synthesis. J. Hydrol. 375, 90-102. https://doi.org/10.1016/j.jhydrol.2008.12.012

Descroix, L., Moussa, I. B., Genthon, P., Sighomnou, D., Mahé, G., Mamadou, I., Vandervaere, J.-P., Gautier, E., Maiga, O. F., Rajot, J.-L., Abdou, M. M., Dessay, N., Ingatan, A., Noma, I., Yéro, K.S., Karambiri, H., Fensholt, R., Albergel, J., and Olivry, J.-C.: Impact of Drought and Land - Use Changes on Surface - Wa-ter Quality and Quantity: 
697

698

699

700

701

702

703

704

705

706

707

708

709

710

711

712

713

714

715

716

717

718

719

720

721

722

723

724

725

726

727

728

729

730

731

732

733

734

735

736

737

738

739

740

741

742

743

744

745

746

747

748

749

750

751

752

753

754

755

756

The Sahelian Paradox, Curr. Perspect.Contam. Hydrol. Water Res. Sustain., in: Current Perspectives in Contaminant Hydrology and Water Resources Sustainability, chap. 10, edited by: Bradley, P. M., 243-271, doi:10.5772/54536, 2013

Dieppois, B., Diedhiou, A., Durand, A., Fournier, M., Massei, N., Sebag, D., Xue, Y., Fontaine, B., 2013. Quasidecadal signals of Sahel rainfall and West African monsoon since the mid-twentieth century. J. Geophys. Res. Atmos. 118, 12587-12599. https://doi.org/10.1002/2013JD019681

Dieppois, B., Durand, A., Fournier, M., Diedhiou, A., Fontaine, B., Massei, N., Nouaceur, Z., Sebag, D., 2015. Lowfrequency variability and zonal contrast in Sahel rainfall and Atlantic sea surface temperature teleconnections during the last century. Theor. Appl. Climatol. 121, 139-155. https://doi.org/10.1007/s00704-014-1229-5

Ekström, M., Jones, P.D., Fowler, H.J., Lenderink, G., Buishand, T. a., Conway, D., 2007. Regional climate model data used within the SWURVE project \&ndash; 1: projected changes in seasonal patterns and estimation of PET. Hydrol. Earth Syst. Sci. 11, 1069-1083. https://doi.org/10.5194/hess-11-1069-2007

FAO: Sahel: situation météorologique et état des cultures, Rapport du 11 juin 2004, http://www.fao.org/docrep/006/j2517f/j2517f00.HTM (last access: October 2016), 2004.

Funk, C., Michaelsen, J., Marshall, M., 2012. Mapping recent decadal climate variations in precipitation and temperature across Eastern Africa and the Sahel. Drought and Water Crises, pp. 331-358. CRC Press.

Gal, L., Grippa, M., Hiernaux, P., Pons, L., Kergoat, L., 2017. The paradoxical evolution of runoff in the pastoral Sahel: Analysis of the hydrological changes over the Agoufou watershed (Mali) using the KINEROS-2 model. Hydrol. Earth Syst. Sci. 21, 4591-4613. https://doi.org/10.5194/hess-21-4591-2017

Gyau-Boakye, P., Schultz, G.A., 1994. Filling gaps in runoff time series in west africa. Hydrol. Sci. J. 39, 621-636. https://doi.org/10.1080/02626669409492784

Harris, I., Jones, P.D., Osborn, T.J., Lister, D.H., 2014. Updated high-resolution grids of monthly climatic observations - the CRU TS3.10 Dataset. Int. J. Climatol. 34, 623-642. https://doi.org/10.1002/joc.3711

Herrmann, S.M., Mohr, K.I., 2011. A continental-scale classification of rainfall seasonality regimes in Africa based on gridded precipitation and land surface temperature products. J. Appl. Meteorol. Climatol. 50, 2504-2513. https://doi.org/10.1175/JAMC-D-11-024.1

Hubert, P., Carbonnel, J.P., Chaouche, A., 1989. Segmentation des séries hydrométéorologiques - application à des séries de précipitations et de débits de l'afrique de l'ouest. J. Hydrol. 110, 349-367. https://doi.org/10.1016/00221694(89)90197-2

Hulme, M., Doherty, R., Ngara, T., New, M., Lister, D., 2001. African climate change: 1900-2100. Clim. Res. 17, 145168. https://doi.org/10.3354/cr017145

Hulme, M., Osborn, T.J., Johns, T.C., 1998. Precipitation sensitivity to global warming: Comparison of observations with HadCM2 simulations. Geophys. Res. Lett. 25, 3379. https://doi.org/10.1029/98GL02562

Ibrahim, B., Karambiri, H., Polcher, J., 2015. Hydrological Impacts of the Changes in Simulated Rainfall Fields on Nakanbe Basin in Burkina Faso. Climate 3, 442-458. https://doi.org/10.3390/cli3030442

IPCC, 2014. Climate Change 2014: Impacts, Adaptation, and Vulnerability. Part B: Regional Aspects. Contribution of Working Group II to the Fifth Assessment Report of the Intergovernmental Panel on Climate Change. Cambridge Univ. Press 688. https://doi.org/10.1017/CBO9781107415324.004

Janicot, S., 1992. Spatiotemporal variability of West African rainfall. Part I: Regionalizations and Typings. J. Clim. 5, 489-497. https://doi.org/10.1175/1520-0442(1992)005<0489:SVOWAR>2.0.CO;2

Jones, P.D., 1994. Hemispheric surface air temperature variations: a reanalysis and an update to 1993. J. Clim. 7, 1794-1802. https://doi.org/10.1175/1520-0442(1994)007<1794:HSATVA>2.0.CO;2 
Jones, P.D., Moberg, A., 2003. Hemispheric and large-scale surface air temperature variations: An extensive revision and an update to 2001. J. Clim. 16, 206-223. https://doi.org/10.1175/1520-0442(2003)016<0206:HALSSA>2.0.CO;2

Jury, M.R., 2013. A return to wet conditions over Africa: 1995-2010. Theor. Appl. Climatol. 111, 471-481. https://doi.org/10.1007/s00704-012-0677-z

Kalteh, A.M., Hjorth, P., 2009. Imputation of missing values in a precipitation-runoff process database. Hydrol. Res. 40, 420. https://doi.org/10.2166/nh.2009.001

Kendall, M., 1975. Multivariate analysis. Charles Griffin.

Killick, R., Eckley, I., 2014. changepoint: An R package for changepoint analysis. Journal of statistical software, 58(3), 1-19.

Kim, J.W., Pachepsky, Y.A., 2010. Reconstructing missing daily precipitation data using regression trees and artificial neural networks for SWAT streamflow simulation. J. Hydrol. 394, 305-314. https://doi.org/10.1016/j.jhydrol.2010.09.005

Kling, H., Fuchs, M., Paulin, M., 2012. Runoff conditions in the upper Danube basin under an ensemble of climate change scenarios. J. Hydrol. 424-425, 264-277. https://doi.org/10.1016/j.jhydrol.2012.01.011

Kundzewicz Z.W., Radziejewski M., 2006. Methodologies for trend detection. In: Climate Variability and ChangeHydrological Impacts (FRIEND). S. Demuth, A. Gustard, E. Planos, F. Scatena \& E. Servat (Eds), IAHS Publ. 308, 538-550.

L'Hôte, Y., Dubreuil, P., Lerique, J. ,1996. Carte des types de climats "en Afrique Noire à l'ouest du Congo". Rappels et extension aux régimes hydrologiques. In: L'hydrologie Tropicale: Geoscience et Outil Pour le Développement (Mélanges à la mémoire de Jean Rodier. Paris, mai 1995), 55-65. IAHS Publ. no. 238.

L'Hôte, Y., Mahé, G., Somé, B., Triboulet, J.P., 2002. Analysis of a Sahelian annual rainfall index from 1896 to 2000 ; the drought continues. Hydrol. Sci. J. 47, 563-572. https://doi.org/10.1080/02626660209492960

Le Barbé, L., Lebel, T., 1997. Rainfall climatology of the HAPEX-Sahel region during the years 1950-1990. J. Hydrol. 188-189, 43-73. https://doi.org/10.1016/S0022-1694(96)03154-X

Le Barbé, L., Lebel, T., Tapsoba, D., 2002. Rainfall variability in West Africa during the years 1950-90. J. Clim. 15, 187-202. https://doi.org/10.1175/1520-0442(2002)015<0187:RVIWAD>2.0.CO;2

Lebel, T., 2003. Seasonal cycle and interannual variability of the Sahelian rainfall at hydrological scales. J. Geophys. Res. 108, 8389. https://doi.org/10.1029/2001JD001580

Lebel, T., Ali, A., 2009. Recent trends in the Central and WesternSahel rainfall regime (1990-2007). J. Hydrol. 375, 52-64. https://doi.org/10.1016/j.jhydrol.2008.11.030

Lehner, B., Liermann, C.R., Revenga, C., Vörömsmarty, C., Fekete, B., Crouzet, P., Döll, P., Endejan, M., Frenken, K., Magome, J., Nilsson, C., Robertson, J.C., Rödel, R., Sindorf, N., Wisser, D., 2011. High-resolution mapping of the world's reservoirs and dams for sustainable river-flow management. Front. Ecol. Environ. https://doi.org/10.1890/100125

Liebmann, B., Dole, R.M., Jones, C., Bladé, I., Allured, D., 2010. Influence of choice of time period on global surface temperature trends estimates. Bull. Am. Meteorol. Soc. 1485-1491. https://doi.org/10.1175/2010BAMS3030.1

Lienou, G., Mahe, G., Paturel, J.E., Servat, E., Sighomnou, D., Ekodeck, G.E., Dezetter, A., Dieulin, C., 2008. Evolution des régimes hydrologiques en région équatoriale camerounaise: Un impact de la variabilité climatique en Afrique équatoriale? Hydrol. Sci. J. 53, 789-801. https://doi.org/10.1623/hysj.53.4.789

Machiwal, D., Jha, M.K., 2006. Time series analysis of hydrologic data for water resources planning and management: a review. J. Hydrol. Hydromechanics 54, 237-257. 
817 Mahé, G., L'Hôte, Y., Olivry, J.C., Wotling, G., 2001. Trends and discontinuities in regional rainfall of West and

818

819

820

821

822

823

824

825

826

827

828

829

830

831

832

833

834

835

836

837

838

839

840

841

842

843

844

845

846

847

848

849

850

851

852

853

854

855

856

857

858

859

860

861

862

863

864

865

866

867

868

869

870

871

872

873

874

875

876

Central Africa: 1951-1989. Hydrol. Sci. J. 46, 211-226. https://doi.org/10.1080/02626660109492817

Mahé, G., Lienou, G., Descroix, L., Bamba, F., Paturel, J.E., Laraque, A., Meddi, M., Habaieb, H., Adeaga, O., Dieulin, C., Chahnez Kotti, F., Khomsi, K., 2013. The rivers of Africa: Witness of climate change and human impact on the environment. Hydrol. Process. 27, 2105-2114. https://doi.org/10.1002/hyp.9813

Mahé, G., Paturel, J.E., 2009. 1896-2006 Sahelian annual rainfall variability and runoff increase of Sahelian Rivers. Comptes Rendus - Geosci. 341, 538-546. https://doi.org/10.1016/i.crte.2009.05.002

Mahé, G., Paturel, J.E., Servat, E., Conway, D., Dezetter, A., 2005. The impact of land use change on soil water holding capacity and river flow modelling in the Nakambe River, Burkina-Faso. J. Hydrol. https://doi.org/10.1016/i.jhydrol.2004.04.028

Maidment, R.I., Allan, R.P., Black, E., 2015. Recent observed and simulated changes in precipitation over Africa. Geophys. Res. Lett. 42, 8155-8164. https://doi.org/10.1002/2015GL065765

Mann, H.B., 1945. Nonparametric Tests Against Trend. Econometrica 13, 245. https://doi.org/10.2307/1907187

McCabe, G.J., Wolock, D.M., 2002. A step increase in streamflow in the conterminous United States. Geophys. Res. Lett. 29, 38-1-38-4. https://doi.org/10.1029/2002GL015999

McCartney, M., Forkuor, G., Sood, A., Amisigo, B., Hattermann, F., Muthuwatta, L., 2012. The water resource implications of changing climate in the Volta River Basin, IWMI Research Report. https://doi.org/10.5337/2012.219

Mitchell, T.D., Jones, P.D., 2005. An improved method of constructing a database of monthly climate observations and associated high-resolution grids. Int. J. Climatol. 25, 693-712. https://doi.org/10.1002/joc.1181

Moalafhi, D.B., Sharma, A., Evans, J.P., 2017. Reconstructing hydro-climatological data using dynamical downscaling of reanalysis products in data-sparse regions - Application to the Limpopo catchment in southern Africa. J. Hydrol. Reg. Stud. 12, 378-395. https://doi.org/10.1016/j.ejrh.2017.07.001

Nicholson, S.E., 2013. The West African Sahel: A Review of Recent Studies on the Rainfall Regime and Its Interannual Variability. ISRN Meteorol. 2013, 1-32. https://doi.org/10.1155/2013/453521

Nicholson, S.E., Some, B. and Kone, B. (2000). An Analysis of Recent Rainfall Conditions in West Africa, Including the Rainy Seasons of the 1997 El Niño and the 1998 La Niña Years. Journal of Climate, 13, 2628-2640. https://dx.doi.org/10.1175/1520-0442(2000)013<2628:AAORRC>2.0.CO;2

Nka, B.N., Oudin, L., Karambiri, H., Paturel, J.E., Ribstein, P., 2015. Trends in floods in West Africa: Analysis based on 11 catchments in the region. Hydrol. Earth Syst. Sci. 19, 4707-4719. https://doi.org/10.5194/hess-19-4707-2015

Ogungbenro, S.B., Morakinyo, T.E., 2014. Rainfall distribution and change detection across climatic zones in Nigeria. Weather Clim. Extrem. 5, 1-6. https://doi.org/10.1016/..wace.2014.10.002

Ozer, P., Erpicum, M., Demarée, G., Vandiepenbeeck, M., 2003. The Sahelian drought may have ended during the 1990s. Hydrol. Sci. J. 48, 489-492. https://doi.org/10.1623/hysj.48.3.489.45285

Page, E.S., 1954. Continuous Inspection Schemes. Biometrika 41, 100. https://doi.org/10.2307/2333009

Peterson, T.C., Vose, R.S., 1997. An Overview of the Global Historical Climatology Network Temperature Database. Bull. Am. Meteorol. Soc. 78, 2837-2849. https://doi.org/10.1175/1520-0477(1997)078<2837:AOOTGH>2.0.CO;2

Ringard, J., Dieppois, B., Rome, S., Diedhiou, A., Pellarin, T., Konaré, A., Diawara, A., Konaté, D., Dje, B.K., Katiellou, G.L., Seidou Sanda, I., Hassane, B., Vischel, T., Garuma, G.F., Mengistu, G., Camara, M., Diongue, A., Gaye, A.T., Descroix, L., 2016. The intensification of thermal extremes in west Africa. Glob. Planet. Change 139, 6677. https://doi.org/10.1016/j.gloplacha.2015.12.009

Roudier, P., Ducharne, A., Feyen, L., 2014. Climate change impacts on runoff in West Africa: A review. Hydrol. Earth Syst. Sci. https://doi.org/10.5194/hess-18-2789-2014 
Rubin, D.B., 1987. Introduction, in: Multiple Imputation for Nonresponse in Surveys. pp. 1-26. https://doi.org/10.1002/9780470316696.ch1

Schönbrodt, F.D., Perugini, M., 2013. At what sample size do correlations stabilize? J. Res. Pers. 47, 609-612. https://doi.org/10.1016/j.jrp.2013.05.009

Stekhoven, D.J., Bühlmann, P., 2012. Missforest-Non-parametric missing value imputation for mixed-type data. Bioinformatics 28, 112-118. https://doi.org/10.1093/bioinformatics/btr597

Stott, P.A., Gillett, N.P., Hegerl, G.C., Karoly, D.J., Stone, D.A., Zhang, X., Zwiers, F., 2010. Detection and attribution of climate change: A regional perspective. Wiley Interdiscip. Rev. Clim. Chang. 1, $192-211$. https://doi.org/10.1002/wcc.34

Suzuki, R., Shimodaira, H., 2006. Pvclust: An R package for assessing the uncertainty in hierarchical clustering. Bioinformatics 22, 1540-1542. https://doi.org/10.1093/bioinformatics/btl117

Troyanskaya, O., Cantor, M., Sherlock, G., Brown, P., Hastie, T., Tibshirani, R., Botstein, D., Altman, R.B., 2001. Missing value estimation methods for DNA microarrays. Bioinformatics 17, $520-525$. https://doi.org/10.1093/bioinformatics/17.6.520

Tshimanga, R.M., Tshitenge, J.M., Kabuya, P., Alsdorf, D., Mahe, G., Kibukusa, G., Lukanda, V., 2016. A Regional Perceptive of Flood Forecasting and Disaster Management Systems for the Congo River Basin, in: Flood Forecasting: A Global Perspective. pp. 87-124. https://doi.org/10.1016/B978-0-12-801884-2.00002-5

University of East Anglia Climatic Research Unit; Harris, I.C.; Jones, P.D. (2017): CRU TS4.00: Climatic Research Unit (CRU) Time-Series (TS) version 4.00 of high resolution gridded data of month-by-month variation in climate (Jan. 1901- Dec. 2015). Centre for Environmental Data Analysis, 25 May 2017

Van Buuren, S., Oudshoorn, K. (1999). Flexible multivariate imputation by MICE. Leiden, The Netherlands: TNO Prevention Center.

Von Storch, H., 1995. Misuses of Statistical Analysis in Climate. Anal. Clim. Var. Appl. Stat. Tech. 11-26. https://doi.org/10.1007/978-3-662-03744-7

Webster, P.J., Magaña, V.O., Palmer, T.N., Shukla, J., Tomas, R.A., Yanai, M., Yasunari, T., 1998. Monsoons: Processes, predictability, and the prospects for prediction. J. Geophys. Res. Ocean. 103, 14451-14510. https://doi.org/10.1029/97JC02719

Yue, S., Pilon, P., Phinney, B., Cavadias, G., 2002. The influence of autocorrelation on the ability to detect trend in hydrological series. Hydrol. Process. 16, 1807-1829. https://doi.org/10.1002/hyp.1095 


\section{HIGHLIGHTS}

920 - The first imputed streamflow dataset for West and central Africa

921 - Good agreement between historical trends in streamflow and rainfall

922 - Partial modulations of post-1990s rainfall recovery by enhancing evapotranspiration

923 - Decadal modulations of Trends in hydroclimatic trends

924 - Homogenous zones of streamflow and precipitation variability 


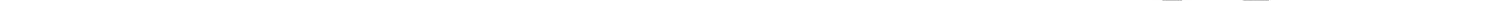




\section{Large Dams in the Study Area}

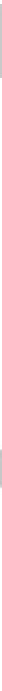




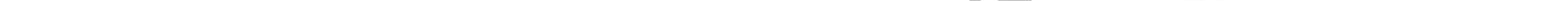




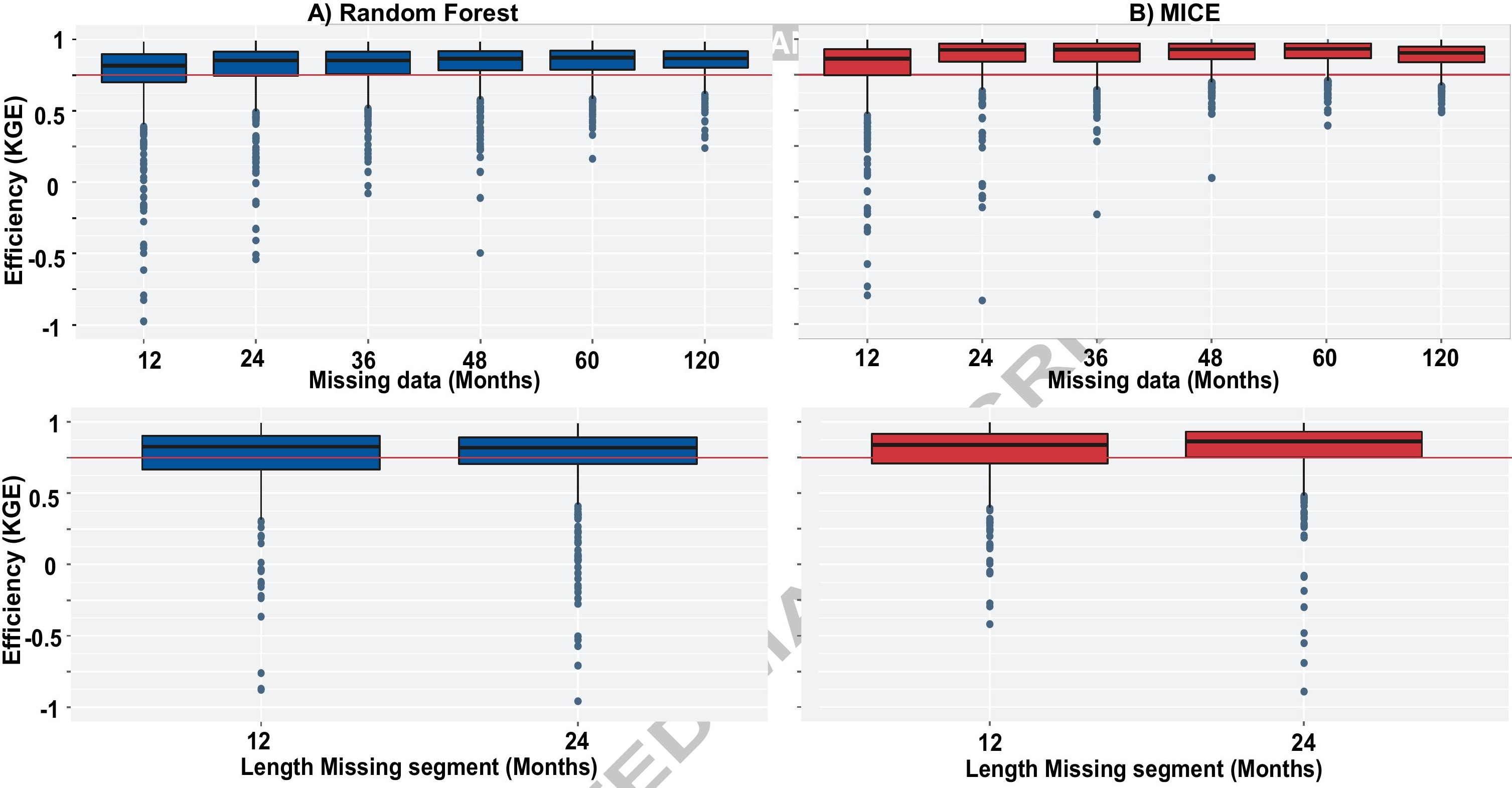




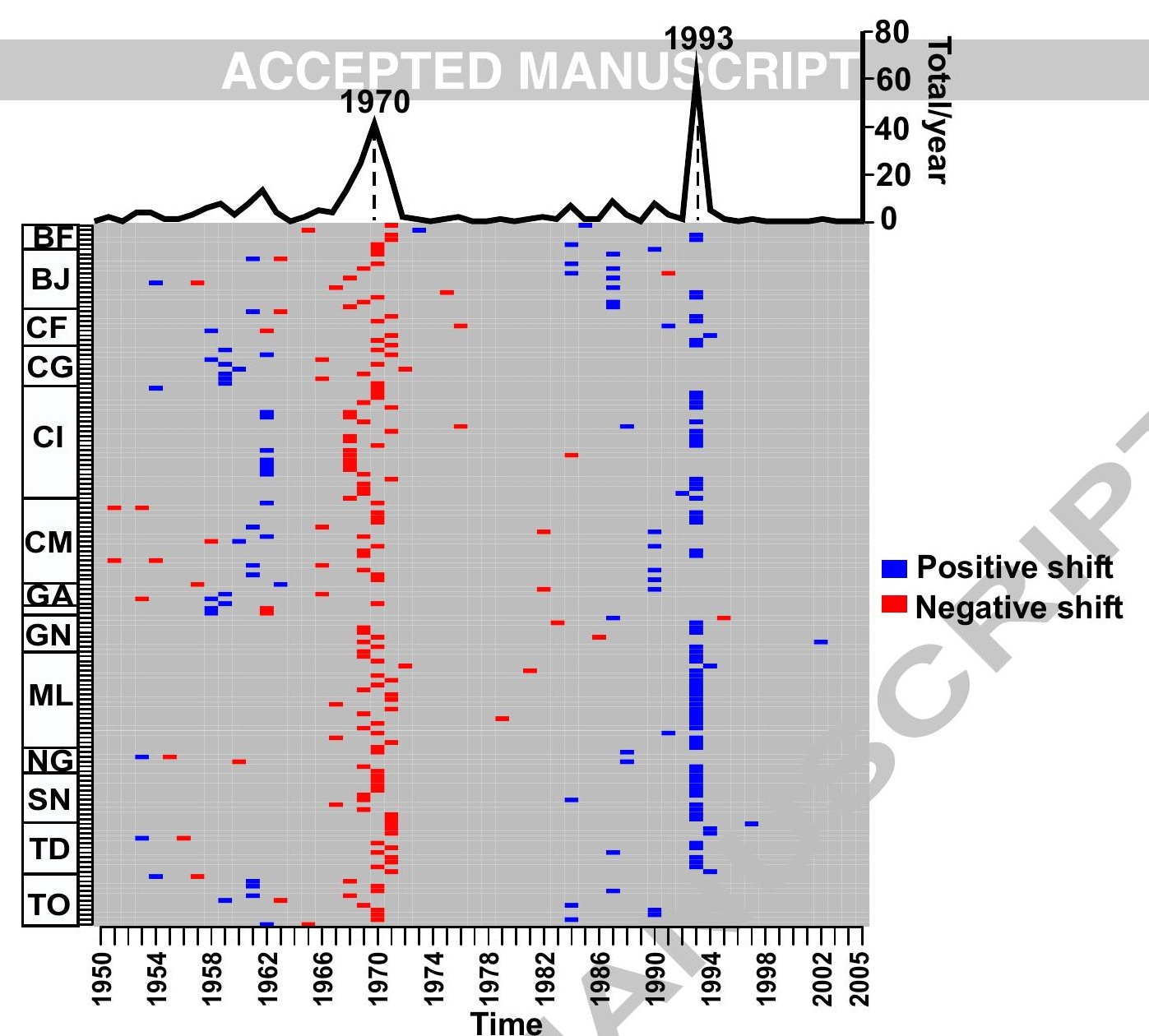




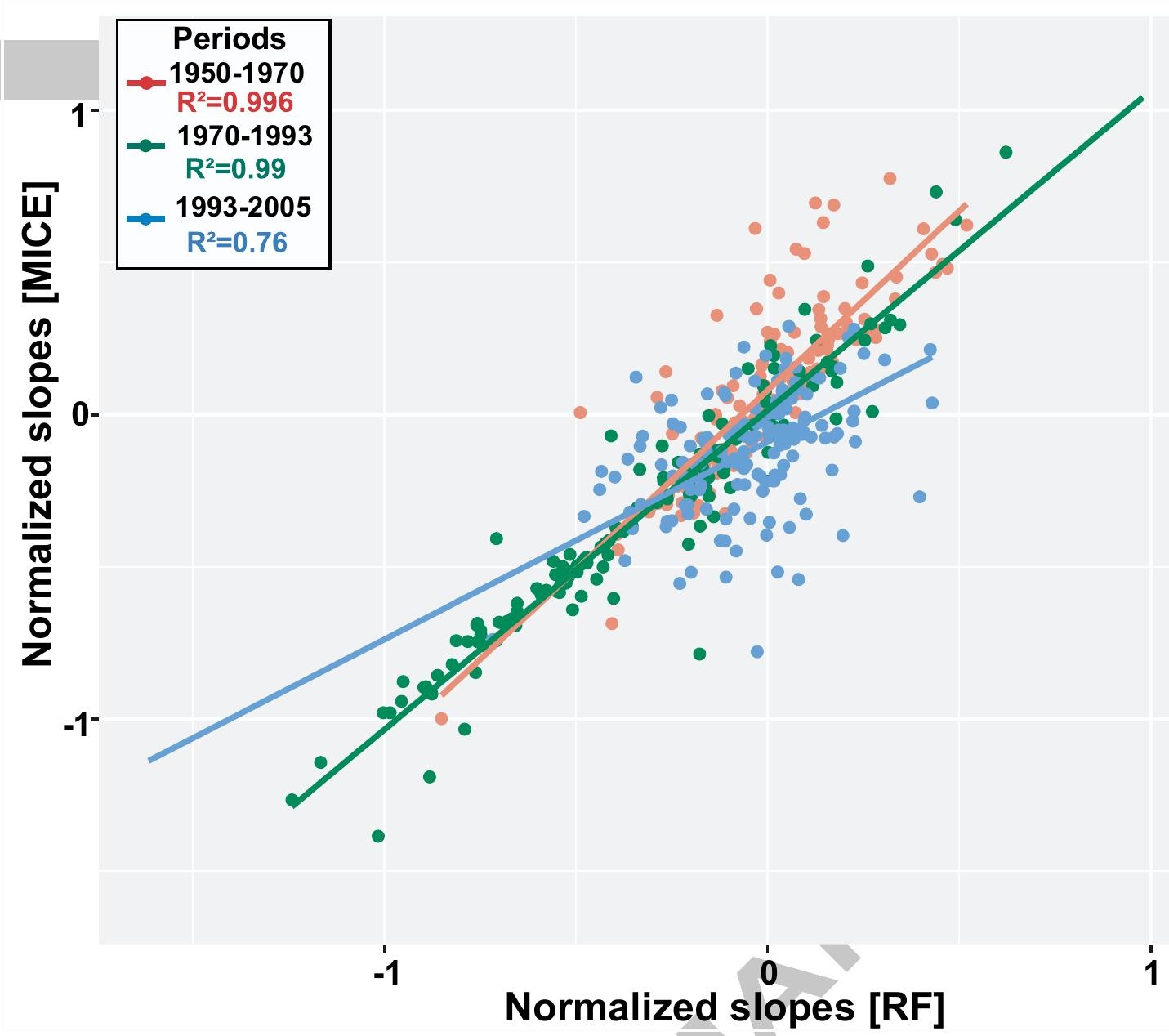



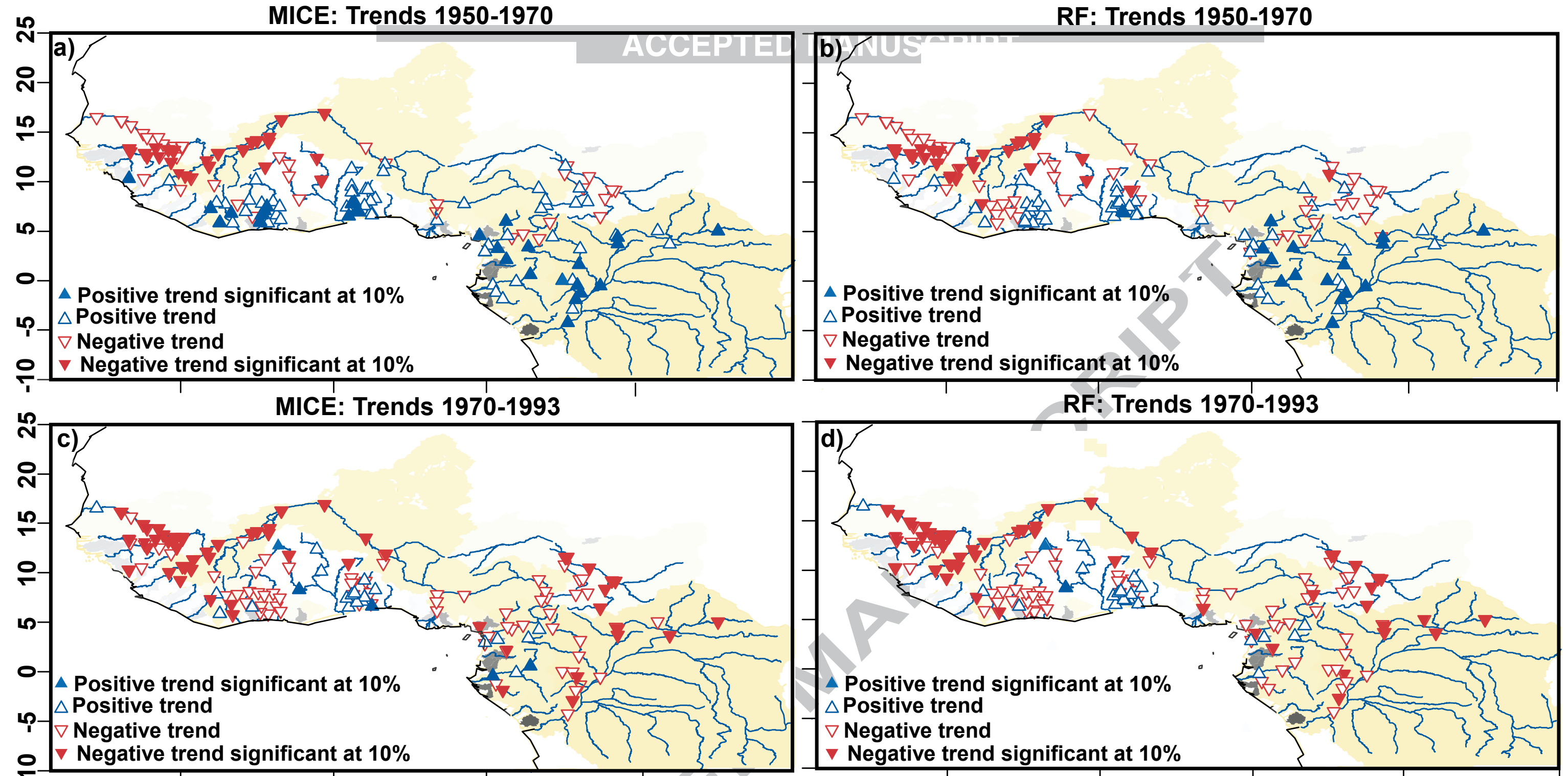

RF: Trends 1970-1993

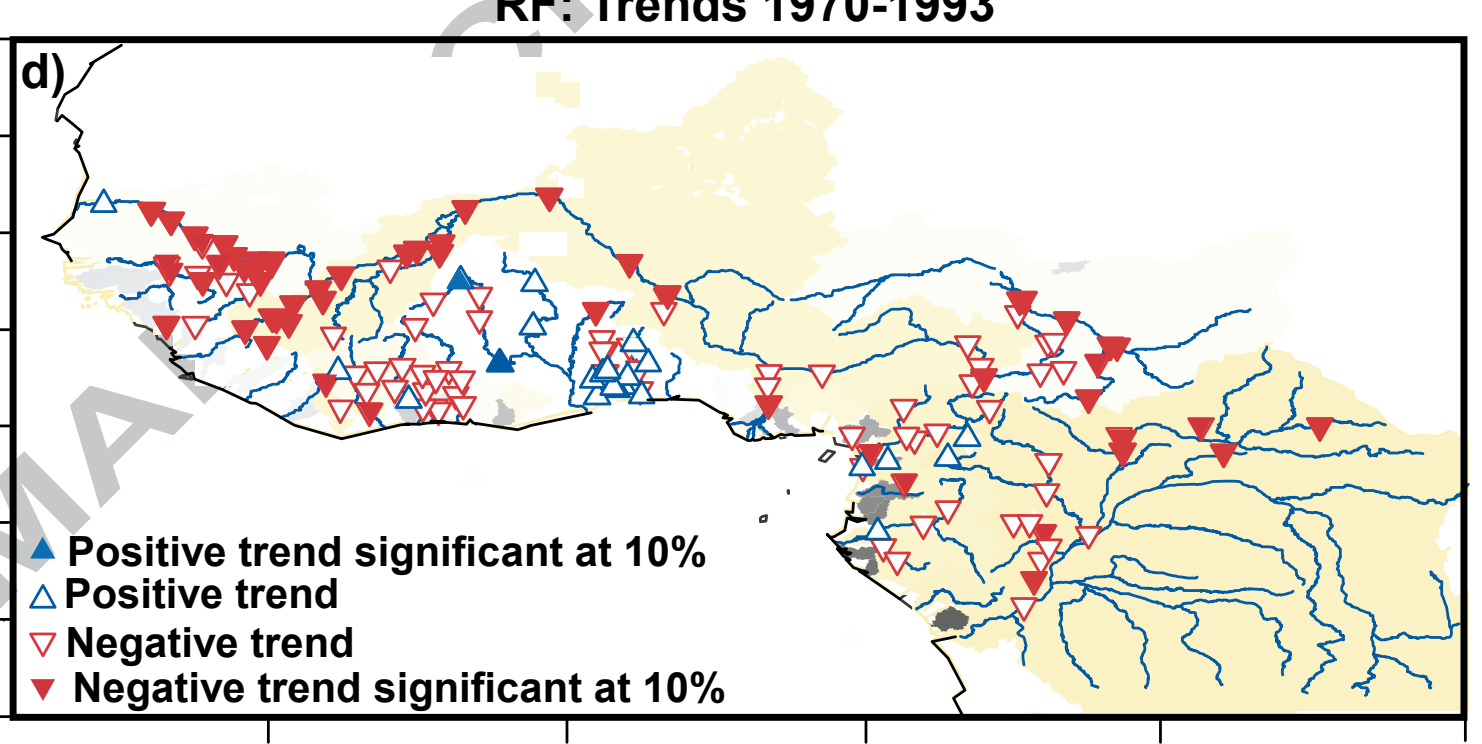

MICE: Trends 1993-2005
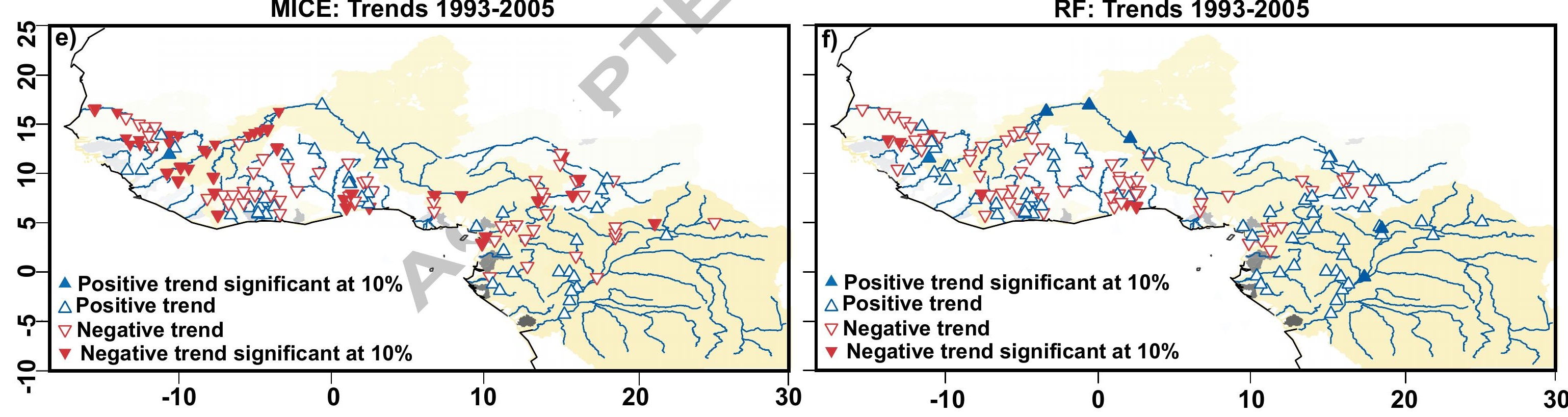


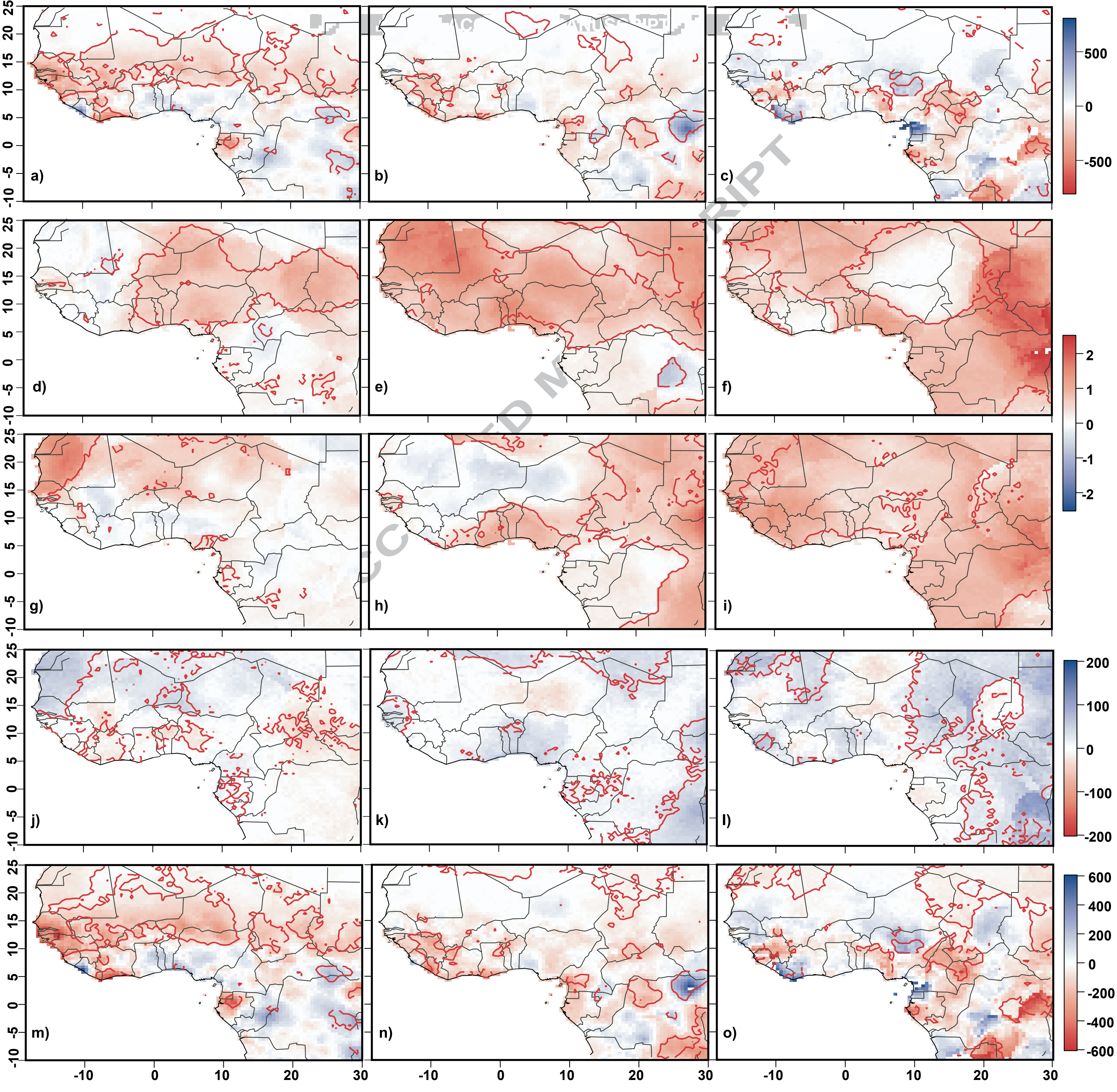




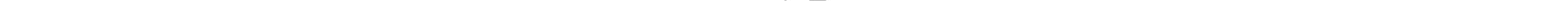


Spatial distribution of rainfall clusters

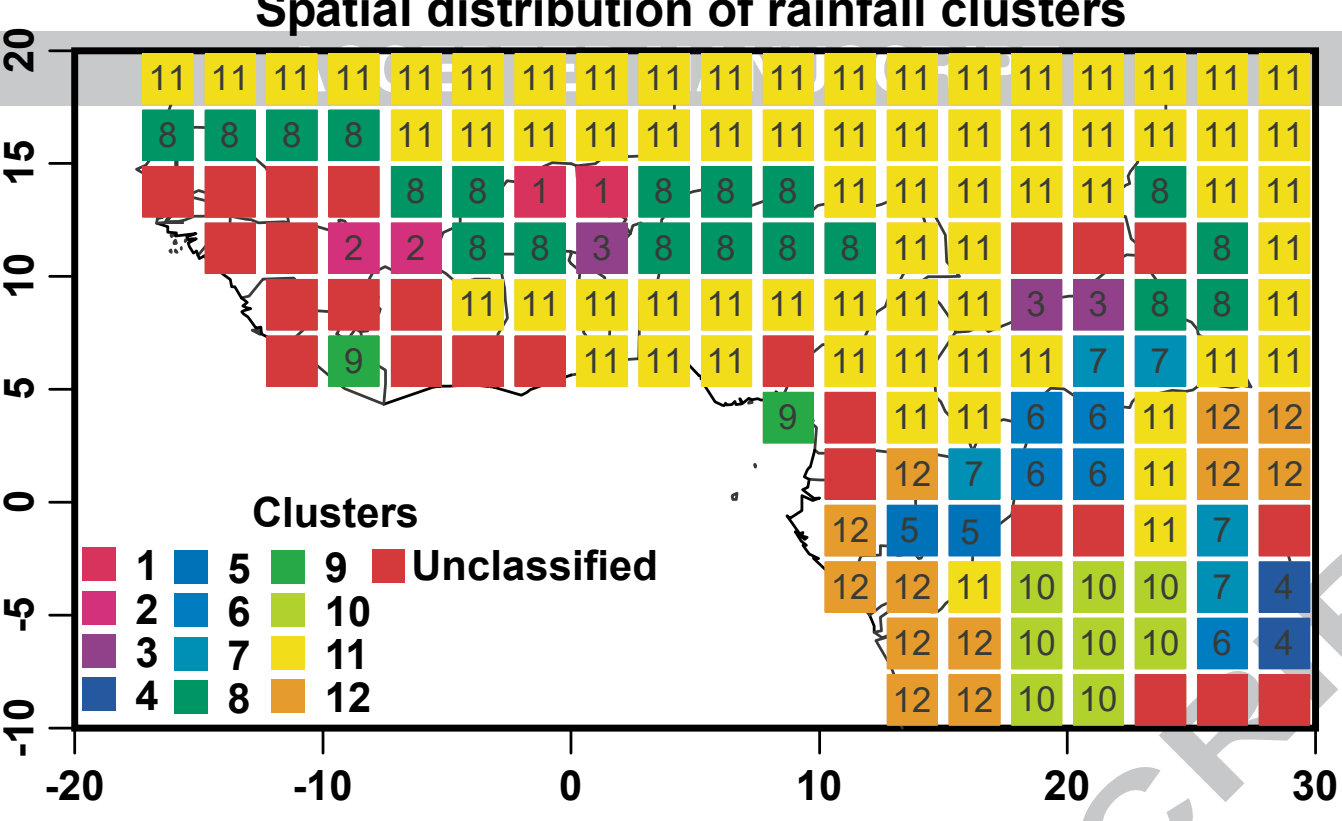




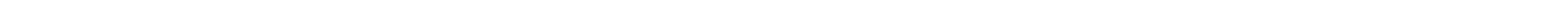

